\title{
The Patient or His Victim: The Therapist's Dilemma
}

\author{
John G. Fleming* \\ Bruce Maximov**
}

A distraught young man seeks help and counsel from a psychotherapist. During treatment he confides his plan to kill his former lover, who has jilted him and destroyed his pride. The therapist believes him. What inust he do? If he warns the potential victim or alerts the police, he violates confidentiality, jeopardizing the therapeutic relationship and, with it, perhaps the best chance of preventing the threatened harn. If instead he relies on his ability to dissuade the young man in time and fails, an innocent person's life may be lost.

That this is no idle school hypothetical is borne out by Tarasoff $v$. Regents of the University of California, ${ }^{1}$ a case presently before the Supreme Court of California. We do not propose to discuss that case as such, lest we get entangled in or limited by its specific facts or the posture in which it is now being considered on appeal. ${ }^{2}$ Rather, we prefer to explore the therapist's dilemma ${ }^{3}$ as a general model, in search of an acceptable accommodation between his potentially conflicting obligations to the patient and to the threatened victim. Alternatively, we can formulate the issue using the conventional terminology of torts, by asking whether a therapist in this delicate situation owes to the threatened victim a duty of reasonable care compatible with his responsibility for safeguarding relevant interests of the patient.

The question of whether the law imposes on the therapist a duty

* Shannon Cecil Turner Professor of Law, University of California, Berkeley. B.A. 1939, M.A. 1943, D. Phil. 1948, D.C.L. 1959 (Oxon.).

** Head Article Editor, California Law Review. B.A. 1969, Stanford University. 6,1973 ).

1. 108 Cal. Rptr. 878 (1st Dist. 1973); hearing granted, Cal. Sup. Ct. (Sept.

2. The salient facts may be gathered from the pleadings discussed by the Court of Appeal. Id. at 880-81. These are complicated, inter alia, by the status of the defendants as employees of a state instrumentality, the University of California. Consequently one of the principal issues of the appeal concerns the applicability of the protean immunities of the Government Code, with which we do not wish to burden our own discussion except parenthetically.

3. With apologies to George Bernard Shaw. 
to warn or take other protective measures for the safety of the prospective victim of a homicidal patient may be approached on two levels. First is the threshold inquiry of whether, altogether apart from the special features of the doctor-patient relationship, a duty of care to protect a third party in these circumstances is consonant with accepted views of the duty relationship in tortious negligence. Part I will explore this question. Once this threshold is crossed we must still face the second, more troublesome question of the weight to be given to such factors as the confidentiality of the doctor-patient relationship in balancing the rights and therapeutic welfare of the patient against the risk to his potential victim. This latter question will be canvassed in two parts. Part II will analyze these countervailing values, part III the possibilities for an appropriate accommodation between them and the competing concern for public safety.

\section{I}

\section{Duty to Protect a Third Party}

The role of duty in the tort of negligence needs no elaborate restatement liere. Its function is to scrutimize the particular relationship between defendant and plaintiff for any reason that social policy might be opposed to demanding froin the former the exercise of reasonable care for the protection of the latter. ${ }^{4}$ While the common law tradition has imbued us with skepticisin, if not suspicion, of generalization, we nonetheless need principles of a certain level of abstraction. But useful as these principles inay be as starting point or warning sign, we must insist on their role as servants, not masters. This caution is particularly important in an area like the duty to protect third parties, which is singularly sensitive to changing social ideas, and where yesterday's verities are apt to become tomorrow's slibboleths.

A long-suspect lornbook rule has it that "in the absence of a special relationship between the parties, there is no duty to control the conduct of a third person so as to prevent him from causing harm to another." In Califorma jurisprudence, this "general principle of tort law" received perhaps its most notorious benediction in the wellknown case of Richards $v$. Stanley. ${ }^{7}$ There the court demed recovery

4. By thus imputing to duty the negative role of a policy control device we are not unmindful of the recent presumption expressed by Lord Reid in Dorset Yacht Co. v. Home Office, [1970] A.C. 1004, 1027 (in the context of a case involving damage by escaping juvemile detainees) that nowadays negligent injury should be actionable "unless there existed some justification or valid explanation for its exclusion."

5. Richards v. Stanley, 43 Cal. 2d 60, 65, 271 P.2d 23, 27 (1954).

6. Tarasoff v. Regents of Univ. of Cal., 108 Cal. Rptr. 878, 886 (1st Dist. 1973), hearing granted, Cal. Sup. Ct. (Sept. 6, 1973).

7. 43 Cal. 2d 60, 271 P.2d 23 (1954). 
to a plaintiff injured by a thief who had stolen the defendant's car when it was parked in a public place with the key in the ignition. This is not the time for a detailed appraisal of that decision, which seeins to have been influenced largely by Justice Traynor's disbelief that car thieves were any more accident prone than legitimate drivers, ${ }^{8}$ an impression long since demolished by the hard statistics of an authoritative investigation. ${ }^{9}$ Indeed, the California Supreme Court has since recognized Richards as a source of embarrassinent. In Hergenrether $v$. East ${ }^{10}$ it was distinguished on the ground that leaving a truck parked in Redding's skid row created a sufficiently foreseeable risk of an accident by a thief. In Veseley v. Sager ${ }^{11}$ the Court repudiated another early precedent by holding that a bartender who supplied an intoxicated customer with liquor might well become liable to a person whom the drunk injured on the way home. Neither of these decisions, of course, is coinpatible with any supposed general principle of "no duty to control the conduct of a third person so as to prevent him from causing harm to another." (And for our purpose it matters not whether the result be expressed in terms of duty or proximate cause or both.)

Moreover, as Harper and Kime long ago explained in a seminal article,$^{12}$ the special relationship sufficient to generate a duty to con-

8. Id. at 66,271 P.2d at 27 .

9. The increased risk would undoubtedly vary considerably depending on whether the accident happened during the get away or three weeks later, whether the car was parked in the vicinity of a high school, or on other individual factors of the particular happening. See Peck, An Exercise Based on Empirical Data: Liability for Harm Caused by Stolen Automobiles, 1969 Wis. L. REv. 909 (1969).

10. 61 Cal. 2d 440, 393 P.2d 164, 39 Cal. Rptr. 4 (1964).

11. 5 Cal. 3d 153, 486 P.2d 151, 95 Cal. Rptr. 623 (1971). This decision aligns California with the trend of decisions on dramshop liability elsewhere. E.g., Rappaport v. Nichols, 31 N.J. 188, 156 A.2d 1 (1959). Some courts have imposed liability not only on tavern keepers and other commercial purveyors of liquor but also on social hosts. E.g., Brockett v. Kitchen Boyd Motor Co., 24 Cal. App. 3d 87, 100 Cal. Rptr. 752 (5th Dist. 1972) (employer's Christmas party); Wiener v. Gamma Phi Chapter, 258 Ore. 632, 485 P.2d 18 (1971) (fraternity party). Some jurisdictions have even construed the relevant penal statute to afford a remedy to the intoxicated person or minor. E.g., Vance v. United States, 355 F. Supp. 756 (D. Alas. 1973). This is not so where, as in California, liability is based on a common law negligence theory, and contributory negligence is thus recognized as a defense. E.g., Sargent v. Goldberg, 25 Cal. App. 3d 940, 102 Cal. Rptr. 300 (2d Dist. 1972). See inter alia Comment, Dramshop Liability, 57 CalIF. L. Rev. 995 (1969).

12. Harper \& Kime, The Duty to Control the Conduct of Another, 43 YALE L.J. 886 (1934). This analysis has been followed by the textwriters. W. PROSSER, LAW OF TORTS 348-50 (4th ed. 1971) [hereinafter cited as ProsSER]; F. HARPER \& F. JAMES, LAW OF TORTS 1053-58 (1956). J. FLEMING, LAW OF TORTS 146-48 (4th ed. 1971). However, the Restatement (Second) of Torts, like its predecessor, neglects to emphasize the point; while sections 314 A-B and 320 deal with special relation between the tortfeasor and the victim, sections 315-19 deal rather timidly with special relation between the tortfeasor and the party to be controlled. RESTATEMENT (SECOND) OF TORTS (1965). 
trol the conduct of another may be found not only in an antecedent relationship between the defendant and the viction, but also in an antecedent relationship between the defendant and the other. The most familiar illustration is the duty of a parent to control his children so that they do not pose an unreasonable risk of injury to the public. The principle has not been limited to that instance, but also applies to other "situations in which the defendant has control over another who is by reason of some social or mental maladjustment a dangerous person."13

One area in which this principle has been repeatedly tested is the responsibility of a penal institution for violence against others committed by a dangerous convict whoin it had negligently permitted to escape. ${ }^{14}$ In this context duty has had to contend with judicial concern over the legitimacy of scrutimizing in a tort action governinental policy decisions such as whether to set up minimum security detention facilities. ${ }^{15}$ This has sometimes led either to the outright recognition of immunity or to nore covert stratagems for avoiding liability, such as an unfashionable sensitivity to proximate cause. ${ }^{10}$

Speaking with a clearer voice, and nucli closer to our subject, are cases involving negligent control of institutional patients with suicidal or homicidal tendencies. In these cases hospitals have not infrequently been lield responsible for the death by suicide of the patient himself, ${ }^{17}$

13. Harper \& Kime, supra note 12 , at 897-98.

14. The duty of the jailer was applied in two Louisiana companion decisions, Green v. State, 91 So. 2d 153 (La. App. 1956), and Webb v. State, 91 So. 2d 156 (La. App. 1956), as well as in the recent House of Lords decision of Dorset Yacht Co. v. Home Office, [1970] A.C. 1004.

15. So, on the question of duty to furnish police protection at the request of a person threatened, a policy decision between competing demands on limited resources requires immunity from collateral attack via civil liability for negligence: Riss v. City of New York, 22 N.Y.2d 579, 240 N.E.2d 860, 293 N.Y.S.2d 897 (1968). See CaL. Gov'x CoDE $\S 845$ (West 1966). Note that in Schuster v. City of New York, 5 N.Y.2d 75,154 N.E.2d 534, 180 N.Y.S.2d 265 (1958), a duty of care on the part of the police to protect the person threatened from attack was recognized because the police had actively contributed in exposing the plaintiff to the vengeance of his pursuers; they had made the plaintiff's condition worse, not merely failed to improve it.

16. The leading case is Williains v. State, 308 N.Y. 548,127 N.E.2d 545 (1955), in which the New York Court of Appeals unanimously denied liability as a matter of law to the victim of an escapee on the dual grounds that the attack was on the facts unforeseeable and that, in any event, it was improper to interfere with the exercise of governmental authority in establishing minimun security detention. In California, the Government Code creates a categorical immunity. CaL. Gov'r Code $\S 845.8$ (West Supp. 1974).

17. E.g., Meier v. Ross Gen. Hosp., 69 Cal. 2d 420, 445 P.2d 519, 71 Cal. Rptr. 903 (1968); Vistica v. Presbyterian Hosp., 67 Cal. 2d 465, 432 P.2d 193, 62 Cal. Rptr. 577 (1967). Decisions from other states are cited by Prosser, supra note 12, at 172 n.39. 
as well as for violence perpetrated by him against others. ${ }^{18}$ Significantly these cases include instances of inadequate supervision as well as negligent release of inental patients. ${ }^{19}$ Moreover, the complaint was not that the defendants had affirmatively created or increased the risk, but merely that they had failed to take steps to decrease risk for the existence of which they were in no way responsible.

If control over the dangerous person is sufficient to establish a duty, how inucl control will satisfy that requirement? One might postulate that a duty to control is the corollary of a right to control. The usual cases concern prisoners or patients committed to (or at least admitted to) mental institutions, which may account for commonly associating the duty with custodial control. ${ }^{20}$ The rationale belind these cases, however, does not support a distinction between inpatients and outpatients. Admittedly, the degree of control over the latter may well be much less than over the former, and this would certainly be relevant in determining what protective measures could reasonably be expected, but it would not justify a complete negation of duty. A riglit to control might be a prerequisite to any duty to detain or physically restrain the patient. It would not, however, necessarily determine whether the therapist should lave reported the inatter to those with authority to commit or should have warned a person threatened by the patient.

Does the bare establishment of a doctor-patient relationship present sufficient involvement by the therapist to impose on him a corresponding obligation of care to take these lesser initiatives for the safety not only of the patient but also of the public? An affirmative answer is invited, not only by reason and a inature sense of social

18. E.g., Merchants Nat'l Bank \& Trust Co. v. United States, 272 F. Supp. 409 (D.N.D. 1967).

19. Merchants Nat'l Bank \& Trust Co. v. United States, 272 F. Supp. 409 (D.N.D. 1967) (state hospital negligently placed mental patient on a ranch without instructing the ranch owner of the need for strict supervision or sounding the alert in case of escape); Underwood v. United States, 356 F.2d 92 (5th Cir. 1966) (airman's premature release fronı psychiatric ward subsequent to negligence of air force psychiatrist who first treated him in not informing psychiatrist who took over treatment of airman's threats on wife's life). Also, Johnson v. State, 69 Cal. 2d 782, 447 P.2d 352, 73 Cal. Rptr. 240 (1968), dismissed a demurrer to a claim for failure to warn the foster family of a 16-year-old parolee's homicidal tendencies, but this case is not as strong, for by placing the parolee into the Johnson family, the defendant bad $\mathrm{i}_{\mathrm{l}}$ a sense created a foreseeable peril for then which iniposed on it a corresponding duty to warn.

In none of those cases did the defense of sovereign immunity prevail. In Underwood, following Fair v. United States, 234 F.2d 288 (5th Cir. 1956), the negligence was held to be operational and not to involve a "discretionary function" within the meaning of Federal Tort Claims Act. 356 F.2d at 98. The same conclusion was reached in Johnson under corresponding California law. CAL. Gov'T CODE $\$ 820.2$ (West 1966).

20. See, e.g., Restatement (SeCoND) of TorTs $\$ 319$ (1965). 
responsibility, but also by some authority from related contexts. First, there are recent developments regarding a hospital's obligation to render emergency treatment to persons obviously in need of immediate aid. The imdividualistic philosophy denying any legal duty to aid and rescue, which in its heyday triumphed even over the Hippocratic oath, has been modified, especially in the case of publicly supported hospitals. ${ }^{21} \quad$ Beyond that, Wilmington General Hospital v. Manlove ${ }^{22}$ imposed a duty to render emergency care on a private hospital with the somewhat fragile justification that the very existence of an emergency situation constituted a tacit undertaking on which the plaintiff had a right to rely for his protection. More important, an assumption of responsibility was evoked without the first tentative step by the defendant to take control. Such a step had been required in the past even by sympathetic courts bent on circumventing the nonfeasance rule. ${ }^{23}$ Furthermore, the plaintiff's pretended reliance, if not outright fictional, was stretched in Manlove to the point where it could do service whenever there is a plausible expectation of protective care. In other words, the apprehended need for protection engenders a reliance which in turn imposes the duty.

While Manlove involved a two party duty to aid, a inore recent decision found a three-party duty to control one party for the protection of another. In Greenberg v. Barbour ${ }^{24}$ it was alleged that a state mental hospital negligently demed the request for admission of an individual who was known by the hospital to ententain hoinicidal delusions and who afterwards promptly assaulted his private physician. The Pennsylvania federal district court held the latter entitled to a cause of action against the hospital. On the basis of this decision, an even more compelling duty to protect a foreseeable victim would arise a fortiori once the culprit had actually been admitted for therapy and a doctor-patient relationship established.

The preceding survey of relevant case law should dispel any notion that to mipose on therapists a duty to take precautions for the safety of persons threatened by a patient, where due care so requires, is in any way opposed to contemporary ground rules on the duty relationship. On the contrary, there now seems to be sufficient authority to support the conclusion that by entering into a doctor-patient relationship the therapist becomes sufficiently involved to assume some responsibility for the safety, not only of the patient himself, but also of any third person whom the doctor knows to be threatened

21. See Powers, Hospital Emergency Service and the Open Door, 66 MrсH.

L. REv. 1455 (1968). The cases are collected in 35 A.L.R.3d 841 (1971).

22. 54 Del. 15, 174 A.2d 135 (1961).

23. See Prosser, supra note 12, at 345-46.

24. 322 F. Supp. 745 (E.D. Pa. 1971). 
by the patient. A duty to such a third person is by no means limited to situations where a special relationship between them can be founded on an express undertaking by the therapist to warn the plaintiff of an impending attack. ${ }^{25}$ Such a duty of protection may just as well arise from entering into a relation of responsibility with the patient himself. While the precedents for this conclusion thus far have involved only dangerous persons under actual detention (inpatients), their rationale would almost surely seem to include also a physician's assumption of responsibility for outpatients. The degree of control would vary, and with it the protective measures that could be demanded, but there is no reason for altogether withholding a duty of care commensurate to the practical options open to the therapist.

One other factor should not be overlooked. Hospitals and the medical sciences, like other public institutions and professions, are charged with a public interest. Their image of responsibility in our society makes them prime candidates for converting their moral duties into legal ones. ${ }^{26}$ Noblesse oblige. While some of the problems facing these institutions and professions in the discharge of their functions may call for policy decisions which present a plausible case for immumity from tort litigation, claims to immumity require individual and zealous scrutiny.

Again, some such situations are complicated by special factors which might suggest modifying, or conceivably even negating a responsibility that would otherwise be theirs. Thus, in part II we will explore, for exainple, whether the confidentiality of the relationship between therapist and patient, as a necessary condition of successful treatment, should not be given weight in modifying or defining the duty for the protection of third persons.

III

\section{The Psychotherapist's Conflicting Duty to His Patient}

Psychotherapy, it could be asserted mitially, imposes a fiduciary duty upon the therapist not to disclose under any circumstances

25. Liability for failure to warn where defendant had promised to warn plaintiff has been repeatedly affirmed. Fair v. United States, 234 F.2d 288 (5th Cir. 1956) (hospital failed to inform wife or detective agency responsible for her protection of husband's release); Morgan v. County of Yuba, 230 Cal. App. 2d 938, 41 Cal. Rptr. 508 (3d Dist. 1964) (sheriff failed to warn wife of husband's early release from jail).

26. The judicial climate is clearly revealed by Tunkl v. Regents of Univ. of Cal., 60 Cal. 2d 92, 383 P.2d 441, 32 Cal. Rptr. 33 (1963), which disqualified a university hospital from invoking a patient's disclaimer because of its position of overriding public responsibility. See especially Tobriner \& Grodin, The Individual and Public Service Enterprise in the New Industrial State, 55 CaLIF. L. Rev. 1247 (1967). The best example of this policy in the present context is, of course, Wilmington Gen. Hosp. v. Manlove, 54 Del. 15, 174 A.2d 135 (1961). 
matters related to him in confidence. If this assertion is true, the duty must conflict with a duty to protect third parties. Certainly confidentiality plays an important role in psychotherapy, as in all physician-patient relationships. ${ }^{27}$ It finds some recognition in professional codes of ethics, including the Hippocratic oath, ${ }^{28}$ although for the most part such protection is mininal since the canons are weakly worded with gaping exceptions. ${ }^{20}$ Most states, however, including California, have enacted privilege statutes as further protection. ${ }^{30}$ In California, at least, the reason for the psychotherapist-patient privilege, broader in many respects than the physician-patient privilege, is quite clear. As the legislative committee cominent explained:

[P]sychoanalysis and psychotherapy are dependent upon the fullest revelation of the most intimate and embarrassing details of the patient's life. ... [And although] the granting of the privilege may operate in particular cases to withhold relevant information, the imterests of society will be better served if psychiatrists are able to assure patients that their confidences will be protected. ${ }^{31}$

27. The characterization of the doctor's duties as fiduciary is the logical complement to confidentiality's central role in the healing process. D. DAwIDOFF, THB Malpractice of Psychiatrists 43-53 (1973). See generally Slovenko, Psychiatry and a Second Look at the Medical Privilege, 6 WAYNe L. Rev. 175 (1960).

28. The code of ethics for physicians contains this passage:

A physician may not reveal the confidences entrusted to him in the course of medical attendance, or the deficiencies he may observe in the character of patients, unless he is required to do so by law or unless it becomes necessary in order to protect the welfare of the individual or of the community.

American medical association, Principles of Medical Ethics \& 9 (1957), reprinted in D. Sharpe \& M. Head, Problems in Forensic Medicine 372 (1966). Similar language is used in canons for psychologists. 18 AM. PsYCHOLOGIST 56, 57 (1963). The Hippocratic oath reads in part: "[W] attendance on the sick, which ought not to be noised abroad, I will keep silence thereon." See Davidson, Legal and Ethical Aspects of Psychiatric Research, 126 AM. J. Psychiatry 239 (1969). See also R. Slovenko, Psychotherapy, Confidentiality, AND PRIVIleged Communication 198 (1966).

29. See sources cited note 28 supra. See also Louisell \& Sinclair, Foreword: Reflections on the Law of Privileged Communications-The Psychotherapist-Pationt Privilege in Perspective, 59 Calif. L. Rev. 30, 32-33 (1971).

30. See generally R. Slovenko, supra note 28 , at 171-98. The historical development of the psychotherapist-patient privilege is well traced in Louisell \& Sinclair, supra note 29 , at 31-39.

Confidentiality, privilege, and privacy are often used interchangeably. There are, however, distinctions. Confidentiality relates to matters of professional ethics. Privilege is a legal right imposed by statute to protect the client from public disclosure of confidences by testimony from the wituess stand without his permission. Privacy in essence "recognizes the freedom of the individual to pick and choose for himself the time, circumstances, and particularly the extent to which he wishes to share with or withhold from others his attitudes, beliofs, behavior, and opinions." Shah, Privileged Communications, Confidentiality, and Privacy: Privileged Communications, 1 Prof. PsychologX 56, 57 (1969).

31. Cal. Evm. CODE $\& 1014$, Legislative Comment (West 1966). California courts have recognized the policies behind the psyehotherapy privilege. E.g., In re Lif- 
Yet this protection embodied in sections 1010 through 1026 of the Evidence Code, ${ }^{32}$ is not without qualification. Section 1024 expressly negates the privilege "if the psychotherapist has reasonable cause to beheve that the patient is in such mental or emotional condition as to be dangerous to himself or to the person or property of another and that the disclosure of the communication is necessary to prevent the threatened danger."33 The extent to which this and other relevant statutes can be read to provide or supplement a duty to third persons, or to negate a duty to the patient, will be discussed 1ater. $^{34}$

The case law involving patients' complaints against physicians for breach of confidence is as equivocal as the statutory treatment of privilege. While recognizing the physician's duty of nondisclosure as the ground rule, ${ }^{35}$ courts have repeatedly insisted that it must yield to "supervening interests of society,"36 and that the patients interest in confidentiality may be outweighed by "a need to safeguard the security of government or the safety of the public."37 Judicial experience, however, has hitherto been too exiguous to demonstrate with any clarity where the balance must be struck. $^{38}$ Moreover, as will presently appear, the patient's stake in confidentiality is significantly greater in a psychotherapist-patient relationship than it is in the ordinary physician-patient relationship. Before proceding further with that ultimate question, though, we must take notice of some additional incursions upon the citadel of confidentiality.

schutz, 2 Cal. 3d 415, 421-22, 467 P.2d 557, 560-61, 85 Cal. Rptr. 829, 832-33 (1970); Tarasoff v. Regents of Univ. of Cal., 108 Cal. Rptr. 878, 888-89 (1st Dist. 1973), hearing granted, Cal. Sup. Ct. (Sept. 6, 1973) (Elkington, J., concurring).

32. Cal. Evid. CoDe $\$ \S 1010-26$ (West 1966) and (West Supp. 1974).

33. Cal. Evid. CoDE $\S 1024$ (West 1966). The section is quoted in full at note 194 infra.

34. See text accompanying notes 194-200 infra.

35. The source of the duty has been found either in a testimonial privilege statute, if one exists, e.g., Clark v. Geraci, 29 Misc. 2d 791, 208 N.Y.S.2d 564 (Sup. Ct. 1960), or otherwise in the Hippocratic oath or similar canon sanctioned through professional licensing statutes, e.g., Horne v. Patton, 291 Ala. 701, 287 So. 2d 824 (1973). Hammonds v. Aetna Cas. \& Sur. Co., 243 F. Supp. 793 (N.D. Ohio 1965).

36. Horne v. Patton, 291 Ala. 701, 709, 287 So. 2d 824, 830 (1973) (dictum).

- 37. Clark v. Geraci, 29 Misc. 2d 791, 793, 208 N.Y.S.2d 564, 567 (Sup. Ct. 1960), citing Simonsen v. Swenson, 104 Neb. 224, 177 N.W. 831 (1920) (exception to duty of nondisclosure where patient carries contagious disease and disclosure is necessary to prevent its spread).

38. Some of the holdings are obscured by the presence of waiver elements. For example, in Hague v. Williams, 37 N.J. 328,181 A.2d 345 (1962), the court refrained from "delineating the precise outer contours of the exceptions," yet found a qualification to confidentiality where "[t] $]$ he physical conditiou of the patient is made an element of [an insurance] claim." Id. at 336, 181 A.2d at 349. Compare CAL. EvID. CODE $\$ 1016$ (West 1970) (patient-litigant exception to psychotherapist-patient privilege). 


\section{A. Threats to Confidentiality}

Several forces in addition to the "dangerous patient" exception coalesce to impair the psychotherapist's fiduciary obligations to his patient. Frequent involvement with potentially dangerous individuals and self-perception as agents of society give psychotherapists the opportunity and reason to place the interests of third persons above those of the patient. Psychotherapy as a profession is well acquainted with dangerousness, dealing often with individuals whose potential for liarm to themselves and to others is substantial. ${ }^{30}$ Its participation is at times neither neutral nor innocent. Since a frequent goal of treatment is to encourage the patient to discharge suppressed feelings, including aggression and even anger, therapy often involves a period of increased instability immediately preceding a breakthrough. ${ }^{40}$ The result in soine instances is injury, even death, where no such tragedy inight have occurred but for the therapy. ${ }^{41}$

Certainly it was partly in response to these risks that the "dangerous patient" exception and similar legislation in other states ${ }^{42}$ were enacted. The Welfare and Institutions Code, from which the language of this exception seems clearly to have been drawn, ${ }^{43}$ provides

39. The California Law Revision Commission reported that many of the persons for whom the privilege protection was specifically tailored "are seriously disturbed and constitute threats to other persons in the community." CAL. EvID. Code $§ 1014$, Legislative Comment (West 1966).

40. Note, Psychiatrist-Patient Privilege-A Need for the Retention of the Future Crime Exception, 52 Iowa L. Rev. 1170, 1182-83 (1967).

41. One article describes several therapy techniques which have precipitated suicide. For example, a therapist may confront the patient with a self-destructivo introject intending to initiate self-analysis, but discover too late that the patient accepted it as reahity, leading to depression and suicide. Stone, Suicide Precipitated by Psychotherapy, 25 AM. J. Psychotherapy 18, 20-21 (1971). Or the therapist might allow or encourage the development of a symbiotic relationship in which the patient is dependent on the therapist as a parent substitute. He might later attempt to interrupt or reduce the intensity of the relationship, only to discover, again too late, that the patient interpreted this attempt as abandonment and therefore committed suicide. Id. at 25-26.

42. California's "dangerous patient" exception appears related to but may bo broader than those of other states often categorized under tho generic heading "futuro crimes exceptions". See Note, Psychiatrist-Patient Privilege-A Need for the Retention of the Future Crime Exception, 52 Iowa L. REv. 1170 (1967). Certainly the vagueness of the term "dangerous" iniplies a negation of the privilege whether or not a criminal act per se is contemplated. See notes 194-96 and accompanying text infra.

43. The phrase "dangerous to himself or to the person or property of another" has deep historical roots im California, and still deeper roots elsewhere. See, e.g., Slovenko, The Psychiatric Patient, Liberty, and the Law, 13 KANs. L. Rev. 59, 62 n.13 (1964) (common law roots). Throughout it has been used to defino that degrec of mental disturbance required for commitment. The evolutionary changes in language have been minimal. From its first codification in California's original Political Code of 1872, sections 2210-27 (approved March 12, 1872) ("so far disordered in his mind as to endanger health, person, or property"), through the major statutory revisions of 
further means of dealing with the psychologically troubled individual considered dangerous to himself or to others. ${ }^{44}$ Some apparently neutral provisions have historically provided opportunities for the attending physician to detain a potentially dangerous patient. ${ }^{45}$ All of this suggests that psychotherapists are expected to use the special social powers invested in their profession ${ }^{46}$ to act in part as agents

mental health legislation in 1903, ch. 364, $\$ 1$, [1903] Cal. Stats. 502-04 (former CaL. POL. CODE $\S \S 2168-74$ ) (same definitions, new procedures), through its transference to section 5050 of the Welfare and Institutions Code in 1937, ch. 369, $\S 1$, [1937] Cal. Stats. 1122 (no change), through the substantial 1939 revisions of that code (section 5040), ch. 295, $\$ 7,[1939]$ Cal. Stats. 1553 ("persons who ... are of such mental condition that they are dangerous to themselves or to the person or property of others"), and through the reorganization of 1965 (section 5550), ch. 391, § 5, [1965] Cal. Stats. 1654 (no change in definitions), the commitment standard remained essentially the same. Thus, in 1965, the phrase "dangerous to themselves or the person or property of others" was the partial definition of committable mental illness. In that same year, with the inost minor of alterations ("others" became "another"), this terminology was grafted for the first time onto the present Evidence Code to become the "dangerous patient" exception. CAx. Evid. CoDE $\$ 1024$ (West 1966). Interestingly, the Welfare arid Institutions Code definition was abandoned two years later for its present form, "a danger to others, or to himself, or gravely disabled." CAL. WeLF. \& INST’NS CODE $\$ \S 5150,5213,5008(\mathrm{~h})$ (West 1972) and (West Supp. 1973).

44. E.g., CaL. WeIF. \& INST'NS CODE $\$ 5150$ (emergency 72-hour detention), $\S 5201$ (petition by individual), $\S 5213$ (detention for treatment), $\$ \S 5250,5260,5300$ (intensive treatment) (West 1972) and (West Supp. 1973).

45. For nearly thirty years, since the first adoption in 1939 of language similar to the present, ch. 295, \& 4, [1939] Cal. Stats. 1551 (originally CaL. Welf. \& INST'NS CODE $\S 5047$ ), the statute permitting individual petition of another's commiftable mental illness contained an express immunity for such action taken by the physician involved. Ch. 391, \$ 5, [1965] Cal. Stats. 1654 (former CAL. WeLF. \& INST'NS CODE $\S 5551$ ) ("When a petition is filed by [any physician attending the patient, such person shall not] be rendered liable thereby either civilly or criminally if there was probable cause for the making or filing of said petition."). The roots of the petitioning procedure go much deeper than 1939. See, e.g., ch. 364, § 1, [1903] Cal. Stats. 502, 511 (former CAL. PoL. CoDE $\$ \S 2168,2192$ ). The immunity, however, was abandoned with the Lanterman-Petris-Short revisions of 1967 and replaced with a penal sanction for anyone who knowingly makes a false petition. CAL. Welf. \& INST'NS CODE $\S \S 5201,5203$ (West 1972).

46. Persons within the profession have long recognized that psychotherapy is provided a privileged position. A leading psychiatrist expresses this recognition as follows:

Organized psychiatry in the United States is an example of a favored social institution. Not only is psychiatry accorded recognition by state and federal governments; it is also provided with privileges and protections that are withheld from other medical specialities.

T. SZASZ, LAW, LIBERTY AND PSYCHIATRY 79-80 (1963) [hereinafter cited as LAw, LIBERTY] (for a critique see Slovenko, supra note 43). Such privileges and protections encompass "more power than [is granted] the ordinary man to influence the standards of conduct within his community ... [including the permission] to certify the abnormality of certain people by making them become patients." S. HArLECK, THE PoLITICS OF THeRAPY 99 (1971) [hereinafter cited as HALIECK].

Besides the expanded scope of protection purportedly given through the psychotherapist-patient privilege (see text accompanying notes 30-31 supra), California's 
of society dutybound to control potentially disruptive forces. ${ }^{47}$ Psychotherapists have responded to these expectations, as the process of involuntary commitment vividly illustrates. ${ }^{48}$ In many cases the recommendation by his psychiatrist is all that is needed to assure a patient's confinement. ${ }^{49}$ At the very least, the psychiatrict's assertion of the

codes abound wih references to the special duties and powers of the profession. E.g., Cal. Pen. Code $\S 1027$ (West 1970) (insanity plea), $\$ 5068$ (West 1970) (preparole evaluation); CaL. WELF. \& INST'NS CODE \$ 741 (West 1972) (determining appropriate treatment for minor); $C_{A L}$. CoDE Clv. PRo. $\$ 1768$ (West 1972) (marital reconciliation conference). Responsibilities and liabilities, of course, have attached as well. See text accompanying notes 197-200 infra.

47. "One of the main functions of organized psychiatry, and historically the oldest, is the segregation of certain members of society." LAW, LiBERTX, supra note 46 , at 80 . The conception of the psychiatrist as an agent of social control, a task well beyond "the treatment of those who seek his services," is not new, nor particularly surprising. Halleck, A Critique of Current Psychiatric Roles in the Legal Process, 1966 WIs. L. REv. 379 (1966); cf. Goldstein \& Katz, Psychiatrist-Patient Privilege: The GAP Proposal and the Connecticut Statute, 36 CoNN. B.J. 175, 186-87 (1962). See also HALLECK, supra note 46, at 36; R. SLovenko, supra note 28 , at 55-56. In California, sections 2212, 2214 and 2215 of the original Political Code of 1872 (approved March 12, 1872) contained procedures for certification of insanity which required the testimony and judgment of two physicians. Some twenty years before this, appropriations were authorized for the state's insane asylum and its medical staff. Cb. 67, \$ 1, [1852] Cal. Stats. 139.

The Symposium elsewhere includes a fuller discussion of the societal agency role of psychiatrists. See Ellis, Volunteering Children: Parental Commitment of Minors to Mental Institutions, 62 CALIF. L. REv. 840 (1974) (this issue).

48. Some would argue that "involuntary commitment" is a redundancy, pointing out that once committed there is nothing voluntary about mental hospitalization whether self-initiated, court determined, or demanded temporarily on an emergency basis. See note 140 infra. The California Welfare and Institutions Code, in its most recent major revision on the subject (the Lanterman-Petris-Short Act), includes provisions for each of the above commitment variations. CAL. WeLF. \& INST'NS CODE $\$ \S 5003,5150$ et seq., 5250 et seq. (West 1972) and (West Supp. 1974).

49. In 1961 a substantial number of states left all decisions regarding authorized hospitalization to administrators and doctors, the state taking no part. Note, Civil Commitment of the Mentally Ill: Theories and Procedures, 79 HARv. L. REv. 1288, 128889 (1966). To be sure, the courts in California and elsewhere have long been aware of the procedural due process problems often built into mental health legislation. See In re Lambert, 134 Cal. 626, 66 P. 851 (1901), the first of a number of decisions which have resulted in commitment provisions replete with procedural detail designed to safeguard the patient's due process rights. See also Specht v. Patterson, 386 U.S. 605 (1961); Thorn v. Superior Court, 1 Cal. 3d 666, 464 P.2d 56, 83 Cal. Rptr. 600 (1970). But cf. Rouse v. Cameron, 373 F.2d 451 (D.C. Cir. 1966). Some feel, however, that due process in commitment legislation is not a pure benefit, but comes only with traunatic costs for the patient. Wexler, Scoville, et al., The Administration of Psychiatric Justice: Theory and Practice in Arizona, 13 ARLz. L. Rev. 1 (1971).

One good example of the psychiatrist's influence is a California emergency detention provision which authorizes peace officers and certain other designated persons to detain for 72 hours in appropriate facilities persons believed on reasonable cause to be dangerous to themselves or others. CAL. WeLF. \& INST'NS CODE $\$ 5150$ (West Supp. 1974), quoted at note 138 infra. The recommendation of the attending psychotherapist is a primary source of information upon which to base such discretionary 
patient's dangerousness to self or to others is prima facie evidence calling for rebuttal to avoid commitment. ${ }^{50}$ Yet key concepts such as "dangerousness" are often deliberately left undefined in statutes. ${ }^{51}$ As a result psychiatric judgments are read into the law, the psychotherapist's determinations rarely being challenged in court. ${ }^{52}$

As the profession's ties to society strengthen, the therapist's ability to be adequately concerned about his patient's interests almost necessarily weakens. ${ }^{53}$ Yet these interests deserve not to be jeopardized so easily and seemingly with so little possibility of recourse. Their importance should becoine clearer as we explore several individually.

\section{B. Patient's Interest in Effective Psychotherapy}

Since the present atmospliere of confidentiality is certainly not absolute, we are faced at the outset with the question whether effec-

action, which is unreviewed by a court in most instances until the 72 hours of emergency detention have passed. Cf. HALlECK, supra note 46, at 166.

The impact of such commitnent must not be minimized because it is temporary. It is a substantial infringement on an individual's freedom, and is capable of causing severe and lasting harm despite its short duration. See text accompanying uotes 130-36 infra. Furthermore, conversion from emergency 72-hour detention to 14-day treatment is a relatively simple procedure. Even longer involuntary treatment is facilitated by subtle presumptions growing out of the original detention aud extension. CAL. WeLf. \& INST'NS CODE $\$ \S 5150,5250,5260,5300$ (West 1972) and (West Supp. 1974) (provisions respectively for 72-hour detention, 14-day intensive treatment, additional 14-day treatment if suicidal, and additional 90-day treatment if imminently dangerous, outlining the method by which teinporary commitment nay, without extreine difficulty, be converted mto more than three and one-half months of confinement).

A good discussion of questions arising from emergency commitment is Roth, Dayley, \& Lerner, Into the Abyss: Psychiatric Reliability and Emergency Commitment Statutes, 13 SaNTa Clara Law. 400 (1973).

50. As one well-known psychiatrist has pointed out:

When society erroneously assumes that all who are labeled "mentally ill" are dangerous, it becomes careless in protecting their rights. Frequently, an inadequate psychiatric examination or a hasty judicial proceeding allows commitment without ever examining whether there is a real need for confinement .... O Often the committed patient is not informed of his civil rights; he rarely has the opportunity to challenge the committing physician's arguments and almost never is permitted to hire a psychiatrist to support his own case.

HALLECK, supra note 46, at 166.

51. Law, Liberty, supra note 46 , at 46 . "In the minds of the psychiatrist or commiting agency, 'dangerousness' can mean anything from the capacity to do violence to simply offending the sensibilities of other citizens." HALLECK, supra note 46 , at 166.

52. Dershowitz, Psychiatry in the Legal Process: A Knife That Cuts Both Ways, 4 Trial 29, 31 (Feb.-Mar., 1968). For a discussion of the problem in the related context of the criminal insanity defense see HALLECK, supra note 46, at 393-95.

53. Cf. HALleCK, supra note 46, at 119-33; LaW, LiberTy, supra note 46 , at 169. Certainly the characterization of the psychotherapist's role as fiduciary adds 
tive psychotherapy has been substantially disrupted by the very existence of a qualified privilege. If not, then the further question remains: When do obligations by psychotherapists to third persons cause disturbance so severe that effective therapy is precluded? Two distinct kinds of disruption are often identified.

\section{Impact: Deterrence of Patients}

The belief that without the protection of confidentiality patients will be deterred from seeking psychotherapy has been a strong force in the enactment of privilege statutes. This view is shared by psychotherapists and courts alike, ${ }^{54}$ and is often cited as a basic policy justification for forceful protective statutes. ${ }^{55}$ The recent proliferation of privilege exceptions, however, suggests a legislative ambivalence as to policy. ${ }^{56}$ Moreover, two other considerations give pause. First, as the recent major decision In re Lifschutz ${ }^{57}$ noted, the psychotherapy profession has grown, even flourished, despite the qualified na-

strength to the argument that dual obligations are incompatible with the therapist's proper function. See generally sources cited note 27 supra.

54. E.g., HALleck, supra note 46 , at 119 . An often citcd passage is from Taylor v. United States, 222 F.2d 398 (D.C. Cir. 1955):

The psychiatric patient confides more utterly than anyone else in the world. He exposes to the therapist not only what his words directly express; he lays bare his entire self, his dreams, his fantasies, his sins, and his shame. Most patients who undergo psychotherapy know that this is what will be expected of them, and that they caunot get help except on that condition .... It would be too much to expect them to do so if they knew that all they sayand all that the psychiatrist learns from what they say-may be revealed to the whole world from a witness stand.

Id. at 401, quoting from M. GutTMACher \& H. Wentofen, Psychitrky AND tHe LAW 272 (1952).

55. See CAL. Evid. Code $§ 1014$, Legislative Comment (West 1966).

56. At the very least the "dangerous patient" exception modifies the basic psychotherapist-patient privilege. See notes 31-34 supra and text accompanying notes 194-96 infra. A look to the legislative comments accompanying these enactments, however, suggests a different underlying policy than simply balancing the need for privilege against the need for disclosure where dangerous patients are involved. The comments to section 1014 posit as one justification for "grant[ing] to patients of psychiatrists a privilege much broader in scope than the ordinary physician-patient privilege" the desire to avoid the deterrence of "persons in need of treatment . . . . [m]any of [whom] are seriously disturbed and constitute threats to other persons in the community." CAL. EVID. CODE $\$ 1014$, Legislative Comment (West 1966) (emphasis added). The discovery of dangerousness negates, however, the very privilege which arguably attracted the patient in the first place. "[I]t is essential that appropriate action be taken if the psychotherapist becomes convinced during the course of treatment that the patient is a menace to himself or others and the patient refuses to permit the psychotherapist to make the disclosure necessary to prevent the threatened danger." CaI. EvID. CODE $\S 1024$, Law Revision Commission. Comment (West 1966) (emphasis added). One wonders if this juxtaposition does not imply a subtle form of entrapment. See also note 196 and text accompanying notes 173, 194-96 infra.

57. 2 Cal. 3d 415, 467 P.2d 557, 85 Cal. Rptr. 829 (1970). 
ture of the confidentiality afforded. ${ }^{58}$ In that case the California Supreme Court rejected a challenge to the "patient-litigant" exception ${ }^{59}$ and upheld a psychiatrist's conviction for contempt of court in refusing to answer questions regarding his patient's mental state and history. ${ }^{00}$ True, that exception presents a lesser inroad on the patient's autonomy than the "dangerous patient" exception, inasinuch as only the patient himself can trigger its operation. ${ }^{61}$ But this does not affect the validity of the court's general observation that the practice of psychotherapy has remained healthy despite the qualified scope of the evidentiary privilege. A healthy profession, however, is no proof that patients are not being deterred. Given the relative scarcity of psychotherapists, ${ }^{62}$ both elements-profession growth and patient deterrence-may coincide. At present, neither the proposition of deterrence nor of nondeterrence is more than an assertion backed by little if any empirical data. ${ }^{63}$

Second, even if deterrence of some patients is provable, the very atmosphere that deters some might well attract others. Studies show that at least some patients with harmful propensities make disclosures in the form of "cries for help," hoping their disclosures will spur the therapist to take control of thein and thus prevent their misconduct. ${ }^{84}$

58. Id. at 426,467 P.2d at 564,85 Cal. Rptr. at 836 .

59. The "patient-litigant" exception reads in pertinent part:

There is no privilege under this article as to a communication relevant to an issue concerning the mental or emotional condition of the patient if such issue has been tendered by:

(a) The patient ....

CAL. Evid. CODE § 1016 (West 1966).

60. The action arose on a petition for habeas corpus following Dr. Lifschutz's confinement for refusing to comply with an order that he respond to questions on deposition concerning his patient's mental condition. The patient instituted a suit for damages for an alleged assault, and the court held that he had tendered the issue, thus negating the privilege to the extent of a narrow inquiry as to relevant matters. 2 Cal. 3d at 420-21, 439, 467 P.2d at 559-60, 573, 85 Cal. Rptr. at 831-32, 845 .

61. The court emphasized this element of inplied waiver by the patient. "[S]ince the exception compels disclosure only in cases in which the patient's own action initiates the exposure, 'intrusion' into a patient's privacy renains essentially. under the patient's control. As such, we find no constitutional infirmity in it." 2 Cal. $3 \mathrm{~d}$.at 433, $467 \mathrm{P} .2 \mathrm{~d}$ at $568,85 \mathrm{Cal}$. Rptr. at 840 . There is no such prerequisite of waiver where the "dangerous patient" exception in involved. See notes 115-20 and accompanying text infra.

62. Comment, Underprivileged Communications: Extension of the Psychotherapist-Patient Privilege to Patients of Psychiatric Social Workers, 61 CaLIF. L. REv. 1050, 1051 (1973); cf. Slovenko, supra note 43, at 74.

63. Indeed, deterrence is always a difficult matter to prove empirically. How many more patients would seek psychotherapy were confidentiality absolute is as elusive of determination as the deterrent impact on crime of any specific penalty. Considerations other than privacy go into the calculus of seeking or avoiding therapy, just as considerations other than the potential penalty if caught go into a criminal's calculations.

64. Goldstein \& Katz, supra note 47 , at 188. 
Were privilege absolute these patients might believe their disclosures futile and resort instead to criminal gestures, also meant as "cries for help" but often with disastrous consequences for both the patient and others. ${ }^{65}$ Lesser confidentiality arguably attracts these patients to therapy. Thus, even if deterrence is a significant factor, qualifying the privilege might nonetheless effect a justifiable trade-off by attracting some patients with dangerous tendencies at the cost of deterring other patients likely to be less dangerous. Numbers are a matter of speculation at this point, but even if the latter group were much larger than the former, such a trade-off might still serve the greater public good..$^{\text {ab }}$

\section{Impact: Interference with Treatment}

Confidentiality, it is generally argued, is even more important for effective treatment than for establishing the patient relationship. ${ }^{07}$

65. Suicide, where the gestures are self-destructive rather than directed toward others, is most illustrative. In one study 22 percent (19 percent of men and 32 percent of women) of completed suicides had communicated a suicidal intent by making a a suicide attempt. Robins, et al., The Communication of Suicidal Intent: A Study of 134 Consecutive Cases of Successful (Completed) Suicide, 115 AM. J. PsYchInTRY 724, 726 (1959). Over two-thirds had communicated suicidal ideas and 41 percent had specifically stated they intended to commit suicide. Id. at 733. Even more striking "[i]n the majority of instances, the suicidal communications were of recent onset (months), repeatedly verbalized, and expressed to many persons." Id. This unfortunate method of alerting others to a suicidal intent, often undertaken openly and persistently, has been noted in numerous studies. See, e.g., Murphy, Clinical Identification of Suicidal Risk, 27 ARCH. GEN. PsYCHiATRY 356, 358 (1972) (probably one-fourth to one-third of suicidal individuals come to medical attention as a consequence of suicide attempts, and many more make attempts than evcr commit suicide). See also Dorpat \& Ripley, The Relationship Between Attempted Suicide and Committed Suicide, 8 COMP. PsYCHIATRY 74 (1967).

66. Assume that those truly intent upon injuring others are deterred by qualified confidentiality, since it might interfere with their plans. Assume further that those whose harmful intentions are actually only cries for help are attracted by qualified confidentiality, since this might allow the therapist to take control of them. From there it is an easy step to the proposition that the goal of societal protcction is better served by a privilege widely known to be qualified than by one gencrally believed to be nearly absolute. The kinds of "dangerous" patients a qualified privilege would attract are precisely those the therapist can help-those more likely to disclose their intentions-while those deterred are the people less likely to make disclosures that would trigger action. Cf. Goldstein \& Katz, supra note 47, at 188. But see CaL. EVID. CODE \& 1014, Legislative Comment (West 1966), that "the interests of society will be better served if psychiatrists are able to assure patients that their confidences will be protected." Information regarding the limits of confidentiality supplied at the beginning of treatment might proinote this goal. See text accompanying notes 182-85 infra. The victims, of course, are those non-dangerous prospective patients in need of help who misunderstand the qualification to apply to a wider range of disclosures than those indicating a serious, harmful intention or a propensity toward dangerous gestures.

67. To help overcome a natural reluctance to seeking treatment, "patients need and expect assurance that their disclosures will remain confidential ..... Once in treatment, it is even clearer that all patients would be affected by the absence of con- 
Indeed, an element of psychotherapy usually assumed essential is the patient's trust that matters disclosed in therapy will be held in strictest confidence. ${ }^{68}$ Most would agree that conducting effective therapy on stage in front of an audience is unthinkable. ${ }^{99}$ This does not mean, however, that without total privacy therapy cannot be effective; certainly it is a matter of degree. Pre-treatment agreements limiting the confidentiality within which therapy will be conducted are not at all unusual. ${ }^{70}$ The very possibility of voluntarily constricting confidentiality, let alone the success claimed through the use of this method, would appear to place the interference concern on somewhat shaky ground.

An examination of the role of confidentiality in group therapy further undermines the interference argument. In group therapy, the therapist conducts simultaneous treatment for a number of patients, who often (and preferably) have some characteristics in com-

fidentiality. . . . At best, the possibility of disclosure will prolong treatment; at worst, it will make thorough exploration of emotional conflicts impossible." Goldstein \& Katz, supra note 47 , at $178-79$.

68. Confidentiality of communication is only one prerequisite to treatment. It sets the stage for an exchange of thought, word and action at the emotional level. Without trust, there can be no proper transference. In fact, the essence of much psychotherapy is the learning of trust in the external world by the formation of a trusting relationship with the therapist. This becomes the model for trust in the external world and ultimately in the self.

DawidofF, supra note 27 , at 44 . See also Slovenko, supra note 27 , at 185-86 (inviolability of confidence essential to achieving the purpose of the relationship).

69. However, two examples to the contrary should be cited. First, videotape is widely used in psychotherapy, especially group work. More and more frequently patients are being asked to release the tapes once thoroughly cleansed of identifying audio references for training purposes. Even cleansed, videotaping certainly poses a more severe threat of public disclosure than, say, the use of coded written case histories for training purposes. See generally Resnick, et al., Videotape Confrontation After Attempted Suicide, 130 AM. J. Psychitry 460 (1973); Lamberd, et al., A Study of Self-Image Experience in Student Psychotherapists, 155 J. Nerv. \& MENT. Disease 184 (1972); Eisler, et al., Videotape: A Method for the Controlled Observation of Nonverbal Interpersonal Behavior, 4 BeHAvioR THERAPY 420 (1973). Moreover, personal identification was coneeded before a nationwide audience in recent programs aired on the Public Broadcasting Service. The series involved a real family, the William Loud household, fully identified, confronting real and in some cases traumatic interpersonal difficulties. There, if nowhere else, the disclosure of intimate persoual details was made on a stage without compensation to the participants by the film makers. Yet it is the privacy of such disclosures which forms the rationale for psychotherapeutic confidentiality. See Spy Drama (Editorial), NAtion, Mar. 5, 1973, at 293; Sample of One?, TIME, Feb. 26, 1973, at 51; Ultimate Soap Opera, Time, Jan. 22, 1973, at 36; "An American Family": Things are keen but could be keener, N.Y. Times Magazine, Feb. 18, 1973, at 8.

70. Interview with Martin Bauman, M.D., Sonoma County Mental Health Department, in Santa Rosa, Cal., Oct. 24, 1973. The role of contracts runs through the entirety of the psychotherapist-patient relationship. See generally Alexander \& Szasz, From Contract to Status via Psychiatry, 13 SaNTA Clara LAW. 537, 548-56 (1973). 
mon, using interactions between patient and therapist or among the patients themselves as means for exposing and solving problems confronting members of the group. ${ }^{71}$ Despite the fact that groups are usually instructed to inaintain internal confidentiality, this method of therapy is typically conducted in an environment less conducive to full confidentiality than that of individual psychotherapy. ${ }^{72}$ Numbers alone increase the chances of an improvident disclosure outside. Moreover groups, especially family groups, often contain individuals whose interests are at variance, or may in fact be directly in conflict, with those of others in the group. ${ }^{73}$ Personal disclosures in such a highly volatile atmosphere run a substantial risk of being revealed outside therapy. Despite this danger each nember is expected to respond in group therapy as fully as he would in private therapy, ${ }^{74}$ and great success is claimed from this process. ${ }^{75}$ In rebuttal it might be contended that group therapy is less likely than individual therapy to attract potentially dangerous individuals. Group therapy, however, is a common feature of community psychiatry, a process which actively

71. A good overview of group psychotherapy, both its historical background and a broad brush description of the various methods involved, is provided in Cross, Privileged Communications Between Partieipants in Group Psychotherapy, 1970 LAW AND THE SOCIAL ORDER 191, 192-93, 194-97 (1970).

[G]roup techniques seek to treat the diseases of interrelated individuals and interrelated groups. The group setting provides insight into problems of social interaction that frequently are unavailable in individual therapy. In short, group therapy is not exclusively egocentric but instead examines many facets of the patient's existence.

Id. at 195. See also H. Durkin, The Group in DePth 26-35 (1964); Note, Group Therapy and Privileged Communication, 43 IND. L.J. 93, 94-95 (1967).

72. Instructions as to internal confidentiality take various forms; some view it as extending the Hippocratic oath to each member. Cross, supra note 71 , at 191 . One rationale for this might be that in group therapy "each patient becomes the therapeutic agent of the others." Id. at 196. More generally such attempts to assure confidentiality simply reflect the widely accepted but not irrefutable assumption that "patients need and expect assurance that their disclosures will remain confidential." Goldstein \& Katz, supra note 47, at 178. See also Fisher, The Psychotherapeutic Professions and the Law of Privileged Communications, 10 WAYNE L. REv, 609, 618 (1964). Whether the Hippocratic oath itself affords the degree of protection generally assumed necessary-or just the illusion of such protection-is by no means clear. See notes 28-29 and accompanying text supra. In any event, despite the asserted need for confidentiality in group process, factors inherent in the group itself often restrict any reasonable expectations of confidentiality. See text accompanying notes 73-75 infra. To assume that group members will maintain a pledge of confidentiality against any forces of lesser magnitude than contempt proceedings is to ignore reality. See Cross, supra note 71, at 191.

73. See DURKIN, supra note 71 at 333-40.

74. In fact, it has been said that "the key to successful therapy lies in the total, unhindered participation of the group's individual members." Cross, supra note 71, at 197 (emphasis added). See note 72 supra. See generally DURKIN, supra notc 71, at $131-43$.

75. E.g., Note, Group Therapy and Privileged Communications, supra note 71, at $93-94$. 
seeks out potentially troublesome individuals. ${ }^{76}$ Moreover, it is a standard treatment method for troubled families, an abundant source of personal violence. ${ }^{77}$

Group therapy's success despite minimal confidentiality suggests two possibilities. One is that despite an awareness of the risks of disclosure group members still respond by fully exposing details about themselves. In short, the degree of trust, that is the confidentiality itself, generally assumed necessary to effective treatment may in fact not be necessary. ${ }^{78}$ Another possibility is that individual participants react to the minimally confidential nature of group therapy by keeping to themselves facts whicl could be injurious if publicly known. Still, success is claimed. Therefore, full discussion might not be as essential as is generally assumed. ${ }^{79}$ In eitler event the group therapy experience strongly suggests that effective treatment is possible in an environment where the patient has little assurance that disclosures will be held in strictest confidence.

Thus it is far from clear whether qualified confidentiality has disturbed the effectiveness of psychotherapy. Even more speculative is the impact of a duty to third persons imposed on therapists, although in all likelihood such an addition would intensify any elements of deterrence or interference already existing. ${ }^{80}$ In any event, substantial disturbance to effective therapy, if proven, still might not outweigh the interest of potential victims. This is the ultimate balance to be struck. But the scales are not yet completely filled, for there are greater de-

76. Community psychiatry includes

[e]fforts to provide total psychiatric care for a carefully defined and himited social unit .... The commitment is to deal with all of the mental health problems in that unit, and not just of those who ask for it. This approach includes techniques to find and treat those who trouble the community.

HALLECR, supra note 46 , at 86 . One reason for group therapy's widespread use in this and similar settings is its low cost. Cross, supra note 71, at 192-93.

77. The statistics for intra-family violence are enlightening as well as saddening. In 1968, 25 percent of all murders in the United States were within a family, the najority between husband and wife; an additional 50 percent of all nuurders resulted from arguments between people who knew each other well; 85 percent of all murders occur within families or among acquaintances. Moreover, 20 percent of all police officers killed in the line of duty between 1960 and 1968 died from wounds received in answering family disturbance calls. Two-thirds of all aggravated assaults occur within a fanily or among friends. R. Clark, CRIME IN AMERICA 51-52 (1970).

78. That groups cannot be successful without full disclosure is the position most often seen in the literature. E.g., Slovenko, supra note 27, at 184-92. The fact of personal disclosure, however, does not necessarily subsume full trust. See note 72 supra.

79. Certainly some methods of individual as well as group therapy operate quite effectively without the need to know detailed, future intentions of the patient. See note 184 and acconipanying text infra.

80. Of course, a duty to third persons might also intensify any elements countervailing deterrence or interference, such as attraction of patients who make disclosures as "cries for help." See notes 64-66 and accompanying text supra. 
mands opposed to this duty to third persons than the interest in effective psychotherapy, whatever its weight. Personal interests of patients, closely akin to established constitutional rights, are also at stake.

\section{Personal Interests of the Patient}

The most crucial concerns of psychotherapy patients involve interests associated with constitutional rights of due process, privacy, and liberty. It is to the protection of these interests, more than any other, that the fiduciary role of the therapist is conventionally thought to be dedicated. In practice, however, some formidable forces are arrayed against this ideal. Two such forces presently besetting the psychotherapeutic profession, each ultimately threatening the fiduciary capacity of the therapist and hence the vital interests of the patient, are the propensity of psychiatrists to overpredict dangerousness and the tendency of the profession to becoine identified with the goals of law enforcement.

Numerous reports confirm that psychiatrists are prone to overpredict dangerousness. ${ }^{81}$ In one study undertaken in New York State, 121 persons adjudged "dangerous criminally insane" were released pursuant to a court order when it was determined that the procedure under which they had been coinmitted was constitutionally defective. ${ }^{\mathbf{2 2}}$ In the four years following release, this group accounted for only sixteen criminal convictions involving no more than nine individualsa rate which is not appreciably higher, if at all, than that expected in a random sample of normal persons. ${ }^{83}$

81. Eight to one overprediction, and thus overcommitment as well, is not unusual. San Francisco Chronicle, December 9, 1973, § A, at 3, col. 1. See Dershowitz, supra note 52 , at 32-33.

82. The state procedure provided for the commitment of prisoners in "security" hospitals and for continued custody at the termination of their sentences, without the degree of judicial determination and review permitted other persons. The Supreme Court found this doubly violative of equal protection. Baxtrom v. Herold, 383 U.S. $107,111,114$ (1966). The placement decision, and thus the determination of dangerousness, was vested in the State Department of Mental Hygiene following an initial judicial determination of committable mental illness. Id. at 110-11.

83. Steadman \& Keveles, The Community Adjustment and Criminal Activity of the Baxtrom Patients: 1966-1970, 129 AM. J. PsychiatrY 80, 83, 304, 307 (1972). The original randoin sample was 246 , but only 121 were released between their transfers in 1966 and October 1970 or death. The sixteen convictions included seven for public drunkenness, four for possessing hypodermic instruments, and one each for vagrancy, petty larceny, and driving a stolen car; the two felonies were grand larceny and armed robbery. Id. See also Hunt \& Wiley, Operation Baxtrom After One Year, 124 AM. J. PsychiatRy 974 (1968). A further statistic of interest is that of the 967 patients affected by the court action, only 26 (2.7 percent) had been returned to Matteawan or Dannemora, New York's two hospitals for the criminally insane, by 1973. Steadman, Follow-up on Baxtrom Patients Returned to Hospitals for the Criminally Insane, 130 AM. J. PsYchIATRY 317 (1973). 
Although such evidence of overprediction-9 correct, 112 incorrect-is startling, ${ }^{84}$ a number of explanations are possible. To a degree, the overprediction may indicate that psychiatrists internalize community sentiment that commitment, even overcommitment, is desirable and expected. ${ }^{85}$ More dramatically, overprediction follows naturally from the inherent imprecision of psychiatric diagnosis. This built-m uncertainty is demonstrated anply elsewhere in this Symposium $^{86}$ and need not be documented in great detail here. ${ }^{87}$ The important observations are: that this imprecision gives psychotherapists broad discretion; that being human they tend to enlarge that discretion because doing so enhances their appearance of power and importance; and that the overcautious attitudes within the community itself influence how the discretion is exercised. The result, quite naturally, is overkill.

Equally threatening is the second, related factor: the occasionally congruent roles of psychotherapist and police officer..$^{88}$ Like the police, psychotherapists are expected to be watchful for indications of developing danger and to take appropriate action, when warranted, to

84. Although the decision to retain Baxtrom in Dannemora State Hospital was made despite the contrary opinions of the testifying psychiatrists, Baxtrom v. Herold, 383 U.S. 107, 112 n.3 (1966), it should not be assumed that non-institutional psychiatrists generally are less inclined to overprediction. Indeed, unless one assumes that commitment or placement panels are peopled by psychiatrists especially prone to overcommitment either from personal predilection or a presumption of dangerousness, it seems the feedback these psychiatrists would receive regarding the overcaution of their decisions would reinforce noncommitment decisions; a reinforcement unavailable to the private psychotherapist who is involved in such determinations less frequently. See note 85 infra.

85. Dr. Henry Steadman has commented upon psychiatrists' tendencies to second guess public desires, and upon the public and legislative support for psychiatrists dubbing certain persons dangerous in order to impose involuntary restrictions upon them. San 'Francisco Chronicle, supra note 81, at col. 4.

86. Ennis \& Litwack, Psychiatry and the Presumption of Expertise: Flipping Coins in the Courtroom, 62 CALIF. L. Rev. 693 (1974) (this issue).

87. One leading spokesman within the profession has urged: "Psychiartists could help society immeasurably . . . if they would frankly admit that current diagnostic categories do not have much scientific meaning-they are largely arbitrary." HALleck, supra note 46, at 104. See LAw, LiberTy, supra note 46, at 194; cf. HALLECK, supra note 46, at 102 . For a general discussion of the problems imherent in vague commitment standards, namely, "overreaching therapeutic goals," see Editors" Forum-Commitment Reform, 55 CALIF. L. 'REv. 1, 2-3 (1967) (editorial comment foreshadowing the 1967 California mental health reform act).

88. This role mixture follows quite naturally from the view of the therapist as an agent of social control. See notes $46-47$ and accompanying text supra. Cf. HALLECK, supra note 46, at 119 (difficult for therapist to protect patient's privacy when confronted with a dual allegiance). The conflicting loyalties may in fact be numerous. Michaels, Guides on Professional Conduct for Psychoanalysts, 17 J. AM. PsYCHOANALYTIC Assoc. 291, 293 (1969). Nor is it clear what action should be permitted in response to these conflicting allegiances. See LAW, LIBERTY, supra note 46 , at $15,197,240$. 
restrain harmful individuals. ${ }^{89}$ Indeed, the psychiatrist in many instances serves not only as arresting officer, but as prosecutor, judge, and jailer as well. ${ }^{30}$ The attending psychiatrists recommendation is usually, in form as well as in substance, both the charge and the evidence in many commitment proceedings. ${ }^{91}$ Not only does a psychiatric panel make the ultimate decision, but deference to the recommendation of the "prosecutor" psychiatrist is the rule rather than the exception. ${ }^{92}$ Mental institutions, of course, are largely staffed by psychiatrists and psychiatric aides, and thus the profession serves in a quasi-párole capacity as well. ${ }^{93}$ In fact, the totalitarian atmosphere of prisons is often mirrored in mental institutions. ${ }^{94}$ For example, even if a patient enters an "open" hospital voluntarily, legally he is still a prisoner. If he decides to leave the hospital a few days after admission against the wishes of the psychiatrist in charge, he may be treated as an escaped prisoner. ${ }^{95}$

\section{Due Process}

Several possible detriments flow froin this assumption of law en-

89. E.g., CAL. Pen. CODE $\$ \S 11160-61$ (West 1970) and (West Supp. 1974) (physician must report injuries inflicted in violation of penal law); $\$ 11161.5$ (West Supp. 1974) (physician must report injuries to minor inflicted by other than accidental-means); CAL. WELF. \& INST'NS CODE $\$ 5150$ (West Supp. 1974) (certain designated hospital staff personnel empowered, along with peace officers, to detain temporarily persons believed dangerously mentally ill).

90. E.g., CAL. WELF. \& INST'NS CODE $\$ \S 5151-52$ (West 1972) (person brought to facility for purpose of 72-hour emergency detention may be admitted, detained, or released in accordance with judgment of professional staff); $\$ 5250$ (West 1972) (14day involuntary intensive treatment following 72-hour emergency detention based on evaluation and decision of facility's professional staff).

91. One comment which offers good analysis of the commitment-incarceration similarities makes this cogent observation:

If a sociologist predicted that a person was eighty per cent likely to commit

$\because$ a felonious act, no law would permit his confmement. On the other hand

if a psychiatrist testified that a person was mentally ill and eighty per cent.

likely to commit a dangerous act, the patient would be committed.

Civil Commitment, supra note 49, at 1290.

92. See notes $49-50$ and accompanying text supra.

93. Compare, e.g., CAL. Welf. \& INST'NS CODE $\$ 5305$ (West 1972) (in judgment of facility's professional staff a patient remanded by court for 90-day intensive treatment may be released at earlier date) with CaL. PEN. Code $\$ \$ 3040-41$ (West 1970) (Adult Authority has power to grant parole at any time after imprisonment subject to $\$ 3043$ et seq.).

94. Commitment to a mental hospital, a "total institution," has been compared to internment in a prisoner of war camp. LAw, LiberTy, supra note 46, at 54.

Commitment is compulsory or involuntary detention of a person in an institution designated as a mental hospital. Like imprisonment in jail, commit-

$\therefore$ ment entails the loss of basic civil liberties. Unlike imprisonment, commitment ostensibly serves a inedical-therapeutic, rather than a judicial-punitive purpose.

1d. at 39 .

95. Id. at 181 . 
forcement roles, not the least of which is lax attention to due process guarantees. ${ }^{96}$ The routines employed may involve invisible regulation of behavior which would not be publicly tolerated were it plainly visible. ${ }^{97}$ In effect, what is created by involuntary commitment procedures is an alternative system of adjudication and control, similar to the criminal justice system but sorely lacking in procedural safeguards. ${ }^{98}$ Just as juries are called upon to decide a person's guilt or innocence, physicians are summoned to determine illness or health. Unlike procedural rules governing trials, however, the rules relating to psychiatric determinations are not clearly formulated; here discretion and arbitrary diagnosis are the hallmarks. ${ }^{99}$ More fundamentally, physicians are trained always to suspect illness. Thus, once a person exhibits some symptoms of illness, he is usually considered sick until proven healthy, ${ }^{100}$ a subtle shift in the burden of proof.

As a result of society's willingness to delegate responsibility to a system ill-equipped to assure that procedural due process standards are met and its lack of concern for the constitutional problems thus posed, commitment akin to incarceration often follows a course quite threatening to the patient. The patient, who has not made an infornied waiver, ${ }^{101}$ makes disclosures to the therapist that lead to his preventive detention pursuant to 72-hour einergency commitment procedures. The "evidence" used, apart from being the product of an invalid waiver, falls within the domain of the patient's right to privacy. ${ }^{102}$ While in teinporary detention he is "tried" and committed. ${ }^{103}$ The burden

96. Id. at $229-30,253$.

97. "We should be clear about the fundamental issue: Should the deed or the doer be punished? We must choose between regulating persons indirectly, by prescribing rules of conduct and penalties for violations, and controlling them directly, through compulsory therapy." Id. at 94.

The converse as well is true. Law enforcement has certain accepted and visible purposes, but covertly serves other and possibly unacceptable purposes such as harassment, unjustified detention and questioning through enforcement of vague disorderly conduct and vagrancy statutes, and indirect provision of social services. H. PACKRR, The Limits of the Criminal Sanction 293-95 (1968).

98. See notes 88-95 supra and notes 103-06 infra.

99. LAW, LIBERTY, supra note 46 , at 224. See notes 81-87 supra.

100. LAW, LIBERTY, supra note 46 , at 224. See also Editor's Forum, supra note 87, at 4 ("professional training and commitment to health may cause" medical examiner to presume illness).

101. For a full discussion of informed consent and waiver see text accompanying notes 159-87 infra.

102. For a full discussion of the patient's right to privacy see text accompanying notes 110-29 infra.

103. E.g., in California 72-hour emergency detention may be followed by certification for 14-day intensive treatment (on the evaluation and recommendation of the professional staff) and in turn followed by 90-day post-certification treatment (on petition by the professional staff). CAL. Werf. \& INST'NS CODE $\$ \S 5150,5250$, 5300-01 (West 1972) and (West Supp. 1974). Additionally, the recommenda- 
of proof placed upon the patient-defendant, the use of self-incriminatory disclosures without an informed waiver, the invasion of privacy, the lax preventive detention standards-all are evidence of violations of personal due process guarantees which would not be tolerated in contemporary criminal proceedings. ${ }^{104}$ In short, commitment to a mental institution, often with a more severe debilitating impact than imprisonment, ${ }^{105}$ frequently follows naturally from a vague determination of dangerousness. In such a system due process is hard put to survive. ${ }^{106}$

Given psychiatry's special position and special powers, ${ }^{107}$ plus society's insistence that it be responsive to the community it serves, ${ }^{108}$ it is little wonder that the pressures on law enforcement to enlist psychiatry as a partner in its formidable tasks, ${ }^{109}$ and the pressures

tion of the professional staff may lead to the appointment of a conservator, and even to indefinite placement in a state hospital. CAL. WeLf. \& INST'NS CODE $\S \S$ 5350-53, 5358 (West 1972) and (West Supp. 1974). California's act provides the patient with substantial possibilities for judicial review following the initial 72hour detention. E.g., CAL. WeLF. \& INST'NS CODE $\$ \S 5275-77,5302-04$ (West 1972) and (West Supp. 1974). It must be borne in mind, however, that California's provisions are of recent vintage and considered quite enlightened, and even strictly enforced judicial review is hard put either to ignore the subtle presumptions which grow from temporary. detention or to minimize the influence of the professional staff's recommendation. Bazelon, Implementing the Right to Treatment, 36 U. CHI. L. REv. 742, 749, 753 (1969). Cf. LAw, LIBERTY, supra note 46, at 176 (even judges consider hospitalization as prima facie evidence of mental illness). See generally Editors' Forum, supra note 87, at 1-7.

104. See, e.g., Miranda v. Arizona, 384 U.S. 436 (1965) (exclusion of statements made without consent to police by persons in custody without proper waiver); Gideon v. Wainwright, 372 U.S. 335 (1963) (right to counsel in criminal proceedings); Mapp v. Ohio, 367 U.S. 643 (1961) (exclusion of evidence obtained in violation of fourth amendment rights); Brinegar v. United States, 338 U.S. 160 (1949) (proof beyond reasonable doubt in all criminal proceedings); cf. Stack v. Boyle, 342 U.S. 1 (1951) (purpose of bail is to assure presence). See also In re Winship, 397 U.S. 358 (1970) (proof beyond reasonable doubt is standard in civil proceeding with disposition akin to incarceration); In re Gault, 387 U.S. 1 (1966) (right to counsel in civil proceeding); Johnson v. Zerbst, 304 U.S. 458 (1938) (strict scrutiny for waiver of constitutional rights); Schaefer, Federalism and State Criminal Procedure, 70 Harv. I. REV. 1 (1956).

105. LAW, LIBERTY, supra note 46 , at $40-41$.

106. Procedural due process guarantees are built into some modern legislation. See, e.g., CAL. WeLf. \& INST'NS CODE $\$ 5252.1$ (West 1972) (certified patient must be informed of rights to habeas corpus and appointed counsel). Often this has resulted from court decisions. E.g., In re Lambert, 134 Cal. 626, 66 P. 851 (1901). Procedural due process guarautees, however, are not widespread, and they do not often affect the generally unreviewed decisions authorizing emergency commitment. See Bazelon, supra note 103, at 753; cf. CAL. WelF. \& INST'NS CODE $\$ 5278$ (West 1972) (professional staff immune froin civil or criminal liability for 72-hour commitment). In any event, the problem of presumed mental illness is not overcome. See generally notes 100,103 supra.

107. See note 46 supra.

108. See note 85 supra.

109. Increases in the number of policemen and advances in the sophistication of their equipment have failed in many instances to keep pace with rising crime rates. Bazelon, Law, Morality, and Civil Liberties, 12 U.C.L.A.L. REv. 13, 25 (1964). 
on psychiatry to succumb thereto, are great. This partnership threatens not only due process, but privacy and liberty as well.

\section{Privacy}

A patient's privacy interests are most obviously threatened by disclosures under "dangerous patient" exceptions to privilege statutes or under ethical standards containing exceptions to confidentiality of similar scope. Both from a constitutional and from a tort perspective such justifications appear suspect. In Griswold v. Connecticut ${ }^{110}$ the United States Supreme Court recognized the right of privacy as a fundamental personal right "within the protected penumbra of specific guarantees of the Bill of Rights."111 Thereby inspired, the California Supreme Court in In re Lifschutz ${ }^{112}$ held that a patient's interest in keeping confidential communications from public purview was constitutionally protected. ${ }^{113}$ This pronouncement has been praised by commentators and finds support in other jurisdictions. ${ }^{114}$ Actually, the court in Lifschutz upheld the "patient-litigant" exception, ${ }^{115}$ but in so doing stressed that in this situation it was entirely within the patient's control whether to waive the protection of his psychotherapy privilege. ${ }^{116}$ This rationale, later reinforced by expression of the court's concern over infornied consent,, ${ }^{117}$ somewhat beclouds the "dangerous patient" exception, which offers no comparable justification. ${ }^{118}$ Indeed, in light of the constitutional dimensions of the right

110. 381 U.S. 479 (1965).

111. Id. at 487 (Goldberg, J., concurring). The right to privacy is explicitly embodied in the California constitution. CaL. Const. art. I, $\$ 1$.

112. 2 Cal. 3d 415, 467 P.2d 557, 85 Cal. Rptr. 829 (1970).

113. Id. at $431-32,467$ P.2d at 567, 85 Cal. Rptr. at 839 .

114. E.g., Louisell \& Sinclair, supra note 29 , at $39-55$. Cases are collected at 44 A.I.R.3d 1 (1972).

115. CaL. EvID. CoDe $\$ 1016$ (West 1970). The pertinent part is quoted at note 59 supra.

116. As the court in Lifschutz expressed it:

[T] he exception compels disclosure only in cases in which the patient's own action mitiates the exposure, [therefore] "intrusion" into a patient's privacy remains essentially under the patient's control. As such, we find no constitutional infirmity in it.

2 Cal. 3d at $432-33,467$ P. 2 d at 568,85 Cal. Rptr. at 840.

117. Roberts v. Superior Court, 9 Cal. 3d 330, 508 P.2d 309, 107 Cal. Rptr. 309' (1973), citing Lifschutz extensively, held that a patient-litigant did not waive ler privilege by the tendering of the issue of personal injury with its necessary but incidental mental component, by the disclosure of the nature of her past psychiatric treatment, by the exchange of her medical reports among physicians, or by the signing of a general insurance consent form. Id. at 339, 341, 343, 508 P.2d at $314,315,316,317$, 107 Cal. Rptr. at 314, 315, 316, 317. See The Supreme Court of California 1972-1973: Roberts v. Superior Court, 62 CALIF. L. REv. 604 (1974).

118. Compare CAL. EvID. CoDE $\$ 1024$ (West 1970) (dangèrous patient) with CaL. Evm. Code $\$ 1016$ (West 1970) (patient-litigant). Whereas the patientlitigant has two choices for avoiding infringement of privacy, either not discussing the 
to privacy and the arbitrariness of the "dangerous patient" standard, ${ }^{110}$ that exception might well be condemned as an unconstitutional infringement upon this fundamental right. ${ }^{20}$

Moreover, aside from constitutional underpinnings ${ }^{121}$ it is hardly questionable that the right to privacy is a highly important interest of the patient which pervades psychotherapy. ${ }^{122}$ There is ainple illustration. For example, inere disclosure of the therapy itself can severely damage the patient's reputation in the community or impair his chances of employment. ${ }^{123}$ The questions concerning psychiatric treatment which arose during the confirnation hearings for Vice President Ford, and the disastrous blight similar revelations cast on Senator Eagleton's vice presidential aspirations the year before, offer but two vivid illustrations from the recent past. ${ }^{124}$ In fact, one critic has noted: "Unlike

matter with the therapist or not tendering the issue in suit, the dangerous patient has only the former choice.

119. As one jurist has written:

The statutes themselves too often speak with archaic and infuriating imprecision. And in operation, the agency or court responsible for conmitments typically contents itself with vague statements from a psychiatrist who has conducted a cursory examination that the individual "could be" dangerous or "might be" dangerous. [Such language reflects an] [a]wesome uncertainty about dangerousness.

Bazelon, supra note 92 , at 749.

120. Alternative grounds for attack are available. First, the asserted state interest, permitting psychotherapists to act for society's protection when confronted with dangerous, mentally ill patients (see note 56 supra), might not be compelling, especially given alternative methods of achieving this purpose which infringe less upon the patient's right to privacy-for example, a requirement of informed consent as a precondition to therapy. See text accompanying notes 159-87 infra. Second, the statute might be void for vagueness and overbreadth. E.g., Griswold v. Connecticut, 381 U.S. 479, 485 (1965) (governmental purpose cannot be achieved by means which sweep unnecessarily broadly and thereby invade protected freedoms). The state action requirement of the fourteenth amendment raises intriguing questions. The degree to which psychotherapists are regulated (see, e.g., CAL. BUs. \& PROF. CODE $\$ \$ 2000$ et seq., 2900 et seq. (West 1962); cf. note 89 supra) and their role at times as the equivalent of law enforcement officers (see text accompanying notes 88-92 supra), however, suggest sufficient state involvement for a finding of state action. See Food Employees Local 590 v. Logan Valley Plaza, Inc., 391 U.S. 308 (1968); Burton v. Wilmington Parking Authority, 365 U.S. 715 (1965); Seidenberg v. McSorleys' Old Ale House, Inc., 317 F. Supp. 593 (S.D.N.Y. 1970). But see Moose Lodge No. 107 v. Irvis, 407 U.S. 163 (1972). See generally Developments in the Law-Equal Protection, 82 HARV. L. REv. 1065, 1069-72 (1969).

121. The phrase is borrowed from In re Lifschutz, 2 Cal. 3d 415, 432, 467 P.2d 557, 568, 85 Cal. Rptr. 829, 840 (1970).

122. "We believe that a patient's interest in keeping such confidential revelations from public purview, in retaining this substantial privacy, has deeper roots than the California statute." $I d$. at 431,467 P.2d at 567, 85 Cal. Rptr. at 839. See generally notes 27-31 and accompanying text supra.

123. Slovenko, supra note 27 , at 188-89. "There is a stigma attached in our society to visiting a 'head-shrinker.'" Fisher, supra note 72, at 622 .

124. The degree of national concern accorded the discovery of Senator Eagleton's previous therapy is revealed by the cover stories that appeared that week. E.g., 
the patient suffering an organic illness, a person in psychotherapy, by and large, visits his psychiatrist with the same secrecy that a man goes to a bawdy house."125 The interest of the patient in nondisclosure becomes all the stronger when disclosure involves a psychiatric label which often encourages society to believe that the patient's behavior cannot be controlled. ${ }^{126}$ Much medical terminology is easily misunderstood by the lay public and often viewed by it with undeserved opprobrium. One need look no further than to such terms as honiosexual, psychotic, or sociopathic to appreciate the plight of the labelled patient. ${ }^{127}$

From the patient's standpoint, these interests constitute strong arguments for limiting any disclosure duty, perhaps even for imposing a duty of nondisclosure upon therapists. The patient wants protection: from disclosure of the fact of therapy; froun disclosure of intimate, personal facts; ${ }^{128}$ and from being subjected to a psychiatric label. Quite apart from their constitutional overtones these interests appear at the core of the right to privacy as protected in tort. ${ }^{129}$

\section{Liberty}

Whereas public exposure is involved in threats to a patient's privacy, certain other of his interests may suffer whether or not there is disclosure. Most prominent is his interest in personal liberty which is at stake in any commitment proceeding, whether it ever reaches the public ear or not.

The impact of commitment--both psychological ${ }^{130}$ and practi-

Time, Aug. 7, 1972, at 12. A poll conducted by TIME revealed that, of those who following the disclosure thought Senator Eagleton was then disqualified, more (50 percent) thought so because he had undergone psychiatric treatment than because he had failed to inform Senator McGovern of that fact (33.5 percent). Id. Indeed, some feel the very publicity of the Eagleton affair will discourage others from seeking needed psychotherapy for fear of the stigma that may later attach. The Eagleton Affair: Stigma of Mental Disorder, Scrence NEws, Aug. 5, 1972, at 84.

125. Slovenko, supra note 27 , at 188 n.46. See HALLECK, supra note 46 , at 64 .

126. HalleCK, supra note 46, at 101-02. Cf. nòte 152 infra. "The expression 'mental illness' as a convemient term of derogation, demigration, or thinly veiled attack, has thus become part of everyday life." LAw, LIBERTY, supra note 46, at 20.

127. Cf. Slovenko, supra note 27, at 195 (abstruse words used in psychiatric records might even prejudice a patient's case in court). See also Fisher, supra note 72 , at $620-23$.

128. See note 54 supra.

129. Horne v. Patton, 291 Ala. 701, 287 So. 2d 824 (1973); Prosser, supra note 12, at 807-12. See also Slovenko, supra note 27, at 175 n.2; cases cited at notes 35-38 supra.

130. "The damaging effects of mental hospitalization on the personality of the inmate are most convincingly demonstrated by the fact that so-called chronic patients rarely try to escape." LAW, LiBERTY, supra note 46 , at 180. 
$\mathrm{cal}^{131}$-inevitably is drastic. ${ }^{132}$ Persons detained in mental institutions must often endure long-term separation from their families, friends, and jobs. ${ }^{133}$ These effects are considerable, even when the patient is one whose "cure"134 is in fact best promoted in the totally secure atmosphere commitment is meant to provide. ${ }^{135}$ They are more troubling when extended therapy could have been an adequate alternative. They become fearful when commitment is simply wrong, or when it is based on other than therapeutic needs. ${ }^{136}$

Emergency commitment statutes illustrate these threats to the individual's liberty. Designed to provide for brief intervention to prevent iminediately threatened harm, they obtain in virtually every state. ${ }^{137}$ Typically these emergency commitment statutes confer authority on certain law enforcement officers and psychiatric personnel to detain briefly persons suspected of being dangerous to themselves or others. ${ }^{138}$ They strongly resemble law enforcement's preventive de-

131. Szasz detailed some of the practical effects of commitment:

The committed patient suffers a serious loss of civil rights. In many jurisdictions he is automatically considered legally incompetent: he cannot vote, make valid contracts, marry, divorce, and so forth. In others, incompetency is a separate matter. In either case, the committed person is incarcerated against his will, must suffer invasions of his person and body, cannot communicate freely with the outside world, usually loses his license to operato a motor vehicle, and suffers many other indignities as well.

Id. at $40-41$.

132. See, e.g., note 94 supra. See also Editors' Forum, supra noto 87 at 3 . Several good articles on civil commitment and its effects are worthy of bibliographical mention at this point. Chambers, Alternatives to Civil Commitment of the Mentally Ill: Practical Guides and Constitutional Imperatives, 70 MrCH. L. Rev. 1107 (1972); Gilboy \& Schmidt, "Voluntary" Hospitalization of the Mentally Ill, 66 Nw. U.L. REv. 429 (1971); Gupta \& Kumasaka, Lawyers and Psychiatrists in the Court: Issucs on Civil Commitment, 32 MD. L. REv. 6 (1972); Livermore, Malnquist, \& Meeh1, On the Justification for Civil Commitment, 117 U. PA. L. Rev. 75 (1968). See generally 13 Santa Clara Law. (1973).

133. Editors' Forum, supra note 87, at 3.

134. Some commentators believe it mappropriate to use a medical model in do. scribing psychiatry; they believe social engineering is more accurate. See LAw, LiBERTY, supra note 46, at vii. See also HALLECK, supra note 46, at 18.

135. LAW, LIBERTY, supra note 46 , at 54.

136. It might be otherwise were hospitalization more voluntary and less like preventive detention. Sec Bazelon, supra note 103, at 749. See also noto 94 supra, noto 140 infra, and text accompanying notes 137-54 infra.

137. Roth, Dayley, \& Lerner, Into the Abyss: Psychiatric Reliability and Emergency Commitment Statutes, 13 Santa Clara Law. 400, 412 n.42 (1973). See also Projects-Civil Commitment of the Mentally Ill, 14 U.C.L.A.L. REv. 822, 839 (1967).

138. For example, the California emergency commitment provision reads in pertinent part:

When any person, as a result of mental disorder, is a danger to others, or to himself, or gravely disabled, a peace officer, membor of tho attending staff, as defined by regulation, of an evaluation facility designated by the county, or other professional person desiguated by the county may, upon reasonable cause, take, or cause to be taken, the person into custody and place him in a facility designated by the county and approved by the State Department of Health as a facility for 72-hour treatment and evaluation. 
tention statutes ${ }^{139}$-in fact, arguably all but truly voluntary commitment ${ }^{140}$ could be considered a form of preventive detention. ${ }^{141}$

Criminal preventive detention has been assailed for a number of reasons: the violence it does to the presumption of innocence, ${ }^{142}$ the risk it runs that nonguilty, not to mention guilty but nondangerous, individuals will be criminally punished and otherwise prejudiced without, or at least before, they have been proven guilty; ${ }^{143}$ and the

CAL. WeLF. \& INST'NS CODE $\S 5150$ (West Supp. 1974). See Projects, supra note 137 , at $839-41$.

139. See, e.g., the District of Columbia's provisions for detention prior to trial. [A] judicial officer may order pretrial detention of-

(1) A person charged with a dangerous crime .... if the Government certifies by motion that based on such person's pattern of behavior . . . there is no condition or combination of conditions which will reasonably assure the safety of the community.

D.C. CODE $\S 23-1322$ (1973).

- 140. Some view "voluntary commitment" as a misnomer, or at the very least a misleading concept. For example:

.Truly voluntary hospitalization is virtually nonexistent in public mental institutions in the United States. In some jurisdictions patients may be admitted on a "voluntary commitment," which means that they enter the hospital voluntarily rather than because of legal coercion. However, such persons are not free to leave the hospital, and their commitment is readily converted into an "involuntary" type.

LAw, LiBERTY, supra note 46 , at 40.

141. Chief Judge David L. Bazelon (United States Court of Appeals, District of Columbia Circuit) draws this comparison well, and deserves to be quoted on this poimt at some length. After observing that commitınent based on the rationale of helping the patient depends on actually providing treatment, he turns to cases involving persons either not treatable or whose treatment is too costly in light of success possibilities. [W] henever care is simply custodial, we must be certain beyond a reasonable doubt-and I import this legal phrase deliberately - that the individual truly could not hope to care for himself. And when the rationale for institutionalization is not that the person would be dangerous to himself, but that he would be dangerous to others, we must be even more careful. Whatever justi-

.. - fication we may find in theories of retribution or general deterrence for confining a convicted criminal, the case is quite different when the individual has comunitted no crime. Confinement in this stuation is, to employ an emotive but accurate term, preventive detention. As such, it is appropriate, if ever, only when the probability of future harmful conduct is high indeed. And when prediction is impossible, we cannot ask the individual to suffer from our uncertainty.

Moreover, needless to say, preventive detention demands standards of procedural due process at least as high as in the criminal law. No civil commitment law begins to meet those substantive and procedural standards, either in language or in operation.

Bazelon, supra note 103, at 748-49.

142. Stack v. Boyle,-342 U.S. 1, 4 (1951); Note, Preventive Detention Before Trial, 79 HaRv. L. REv. 1489, 1501 (1966); 116 Cong. REC. 16886 (1970) (remarks of Senator Ervin). See also Note, Constitutional Limitations on the Conditions of Pretrial Detention, 79 YALE L.J. 941, 951 (1970); Hearings on Preventive Detention Before the Subcomm. on Constitutional Rights of the Senate Comm. on the Judiciary, 91st Cong., 2d Sess. (1970) [hereinafter cited as Hearings].

: 143. "Since the Petition of Right of 1628 , it has been clear that the promise of the Magna Charta 'that no man ... shall be ... taken nor imprisoned . . . without 
denial of due process it entails for the detained individual who is prevented from participating in his own defense. ${ }^{144}$ These same dangers are present and perhaps intensified for the patient-often the subject of a psychiatrist's presumption of illness ${ }^{145}$-who is committed under emergency provisions. It is not at all unusual for emergency commitment to be transmuted in a pro forma proceeding into regular involuntary commitment, ${ }^{146}$ especially since the presumption of innocence may continue to be flouted even at the "trial" stage. ${ }^{147}$

In light of the lack of procedural safeguards, psychiatry's notorious inability to predict dangerousness, ${ }^{148}$ and the vagueness of the standards defining coinmittable behavior, ${ }^{149}$ the risk of treatment amounting to punishment without any legitimate need for restraint is great. ${ }^{150}$ In all likelihood, in fact, it is greater than the risk created by criminal preventive detention statutes. ${ }^{151}$ Moreover, once coin-

being brought in answer by due process of law' applies to imprisonment before, as well as after, conviction." Tribe, An Ounce of Detention: Preventive Justice in the World of Joln Mitchell, 56 VA. L. REv. 371, 380 (1970) (footnotes omitted). See also Hearings, supra note 142. But see Preventive Detention Before Trial, supra note 142, at 1501 (due process does not require a trial and conviction before any interference with liberty is permitted).

144. 116 CoNG. Rec. 16886 (1970) (remarks of Senator Ervin). Senator Ervin's statement raises other constitutional problems as well: vagueness, double jeopardy, self-incrimination. Id. The eighth amendment's right to bail and the punishment of status (future dangerousness) have also been raised as constitutional barriers to preventive detention statutes, or at least loosely drafted ones. Robinson v. California, 370 U.S. 660 (1962); Tribe, supra note 143, at 394-96, 404-05. See generally Hearings, supra note 142.

145. See note 100 supra.

146. See note 49 supra.

147. See note 50 supra.

148. See notes $81-85$ and accompanying text supra.

149. See notes 86-87 and accompanying text supra.

150. The risk raises questions of constitntional proportion. See Rouse v. Cameron, 373 F.2d 451 (D.C. Cir. 1966) (committed patient has right to treatment). An interesting coinmentary on Rouse concluded that the case poses a difficult but soluble due process dilemma for the state. It may civilly commit a person for his own protection (parens patriae) with possibly lax procedural due process safeguards, but then must provide adequate treatment; or it may commit the person for the protection of others (preventive detention), but then must supply due process guarantees comparable to those obtaining in the criminal field. Note, Civil Restraint, Mental Illness, and the Right to Treatment, 77 YALE L.J. 87, 100-04 (1967). See also 80 HARv. L. REv. 898, 898-99 (1967). Few states' civil commitment provisions, or emergency detention provisions for that matter, comport with the stringent due process requirements of the latter alternative. Bazelon, supra note 103, at 749 . See notes $155-56$ and accompanying text infra.

151. At least the criminal preventive detention statutes presently enacted demonstrate some degree of precision and certainty in their standards. Sec, e.g., D.C. Code $\$ 23-1322$ (1973), quoted at note 139 supra. Unfortunately, high bail serves as an alternative means, standardless for the most part, to explicit preventive detention statntes. See generally Foote, The Coming Constitutional Crisis in Bail (pts. 1-2), 113 U. PA. L. REv. 959, 1125 (1965). 
mitted, the patient who attempts to establish his health in order to gain release must overcome the psychiatric label which necessarily attaches. ${ }^{152}$ Again, this obstacle may be more forbidding than the corresponding label attached to the suspected criminal. ${ }^{153}$ Finally, because of the prejudicial effects of prolonged institutionalization, the longer the period of commitment the greater the likelihood that the patient's will to resist will be overborne. ${ }^{154}$ All of these factors suggest that emergency commitment as presently codified and practiced, with its extreme discretion, even arbitrariness, and its potentially detrimental impact upon patients, is constitutionally suspect on both substantive and procedural due process grounds. ${ }^{155}$ The underlying statutes on their face and certainly in application, appear to vest the psychiatric profession with unfettered discretion unquestionably threatening to the fundamental right of personal liberty. ${ }^{156}$

Nor, for that matter, is the exercise of these powers in all respects beyond the province of tort proceedings. True, the actual decision to commit is usually vested with immunity, ${ }^{157}$ but those who

152. Szasz discussed the dangers of labeling:

A label, often with ominous connotations-nowadays most patients are called "schizophrenic"-must be attached to every patient. Then, when there is a question of the patient's discharge, future employment, or of some other decision, the label is produced. It frightens everyone, including the doctors.

LAW, LLBERTY, supra note 46, at 175-76 (emphasis in original).

153. See text accompanying notes 123-27 supra.

154. One psychiatrist suggests that this is indicated by the fact that "so-called chronic patients rarely try to escape" from mental hospitals. LAW, LrBERTY, supra note 46 , at 180 . Whether prisoner rebellion is good or bad, it certainly indicates a will to resist evidently prevalent in many prisons today, but seemingly absent among patients committed to mental institutions.

155. See Wexler, Scoville, et al., supra note 49, at 99-100 (citing Minnesota ex. rel. Pearson v. Probate Court, 309 U.S. 270 (1940), for the proposition that past conduct is the only constitutionally permissible basis for emergency detention). The Wexler study opines that California's provisions, at least for cominitment over 14 days in duration, pass constitutional muster. Wexler, Scoville, et al., supra note 49, at 116. A contrary argument is suggested at note 156 infra. For a discussion of California's emergency commitment provisions, see note 49 supra.

156. The constitutional arguments here, especially state action, are similar to those made earlier, at note 120 supra, regarding privacy rights. Liberty, more clearly even than privacy, is a fundainental right. Commitment provisions, especially of an emergency nature and including California's enlightened recent enactments (at least for commitments of fourteen or fewer days), infringe this right, yet are based on a criterion, "dangerousness," which at best is extremely vague and at worst offers no standards whatsoever. Just as certainly as standardless parade permit ordinances grant too broad authority in an effort to serve a permissible governinent function, thus threatening freedom of speech and association, commitment provisions based on "dangerousness" threaten the right to liberty and are therefore constitutionally suspect. See, e.g., Shuttlesworth v. City of Birmingham, 394 U.S. 147 (1969); Lovell v. City of Griffin, 303 U.S. 444 (1937); cf. Carroll v. President \& Comm'rs of Princess Anne, 393 U.S. 175 (1968).

157. E.g., CAL. Welf. \& INST'NS CODE $\S \S 5154,5173,5257,5267,5278,5306$ (West 1972) (individualized immunities for various stages of commitment process); 
merely take the initiative of bringing the case before the comunitting authority, such as the patient's own therapist, usually remain exposed to potential tort liability. ${ }^{158}$

\section{An Overriding Interest: Informed Consent}

Behind the privacy, liberty, and due process imterests is the ob, jection that violations of these interests are inflicted upon patients who begin therapy unaware that confidentiality is limited and assuming that the psychotherapeutic relationship will afford them adequate protection. If one accepts this premise, informed consent becomes central to safeguarding the patient, quite apart from whether his other interests, including the interest in effective treatment, independently demand protection.

The recent Califorma Supreme Court case of Cobbs v. Grant ${ }^{150}$ offers soine insight. In Cobbs the issue was whether a physician failed to inform his patient of possible coinplications to abdominal surgery. ${ }^{160}$ The court held that a physician's obligation to the patient imcludes a duty reasonably to disclose therapy options and the risks involved in each. ${ }^{161}$ Such a disclosure duty follows necessarily froin several postulates. First, the patient has a right to decide whether or not to submit to medical treatment. Second, he is less aware of the risks inherent in treatunent than is the physician. Finally, the patient has an abject dependence upon and trust in the physician. ${ }^{102}$ Therefore, the scope of the duty is "measured by the patient's need, and that need is whatever information is material to the decision."103

CAL. Gov'T CODE $\$ 856$ (West Supp. 1974) (generalized immunity for detcrminations by public employees in scope of employment).

158. See, e.g., CAL. WeLF. \& INST'NS CODE $\S 5203$ (West 1972) (civil liability for knowingly false petition), $\S \S 5255,5265$ (West 1972) (civil liability for excessive detention). Nor is liability limited to statutory law. The tort actions for invasion of privacy, false imprisonment, abuse of process, and infliction of mental distress are all cognizable where unnecessary deprivation of liberty has been caused by anothcr. See Prosser, supra note 12, at 49, 51-52, 327-35, 807-09. Moreover, the attending physician no longer has the express immunity he once was granted. Sec note 45 supra.

159. 8 Cal. 3d 229, 502 P.2d 1, 104 Cal. Rptr. 505 (1972).

160. The original operation was for a duodenal ulcer. The inherent risks of this led to three additional hospitalizations, first for removal of the patient's spleen, later for removal of half his stomach, and finally for treatment for the premature absorption of a suture. Id. at 234-35, 502 P.2d at 4-5, 104 Cal. Rptr. at 508 .

161. Id. at 243, 502 P.2d at 10, 104 Cal. Rptr. at 514; accord, Canterbury v. Spence, 464 F.2d 772 (D.C. Cir. 1972), cert. denied, 409 U.S. 1064 (1972).

162. Cobbs v. Grant, 8 Cal. 3d 229, 242, 502 P.2d 1, 9, 104 Cal. Rptr. 505, 513 (1972).

163. Id. at $245,502 \mathrm{P} .2 \mathrm{~d}$ at $11,104 \mathrm{Cal}$. Rptr. at 515 . The court rejected measuring the duty by "the custom of physicians practicing in the community," vicwing this test as "needlessly overbroad." Id. at 243, 502 P.2d at 10, 104 Cal Rptr. at 514. 
The Cobbs test appears fully applicable to violations of the privacy interests of psychotherapeutic patients. The interest, stressed in Cobbs, ${ }^{104}$ that a person has in controlling what is done to his own body, extends to the psychological distress and pecuniary loss that constitute tort claims for invasion of privacy and infliction of inental distress. ${ }^{105}$ Tort doctrine draws no clear demarcation between bodily and psychological damage. ${ }^{166}$ Thus, the patient's right to self-determination extends as inuch to his interest in privacy and psychological health as to his interest in bodily security. Lack of parity between physician and patient regarding their awareness of risks, the second factor stressed in Cobbs, is equally present in the psychotherapeutic context. ${ }^{167}$ Confidentiality is a protection often assumed by patients to be total, but known by therapists to be severely limited. ${ }^{108}$ Sub-

164. "[A] person of adult years and in sound mind has the right, in the exercise of control over his own body, to determine whether or not to submit to lawful medical treatment." Id. at 242, 502 P.2d at 9, 104 Cal. Rptr. at 513. Lest it be contended here that the court's "in sound mind" qualification automatically removes the informed consent requirement from the circumstance under present consideration, two points must be kept in inind. First, the court's incompetency-emergency standard (id. at 243,502 P.2d at 10, 104 Cal. Rptr. at 514) is not clearly congruent with the vague dangerousness standard which is at the heart of commitment or emergency detention; dangerousness might well be much more inclusive. Indeed, unless the immediacy and unavoidability qualities inherent in the energency situation are grafted onto the dangerousness standard, this latter criterion appears not to fulfill the test adhered to by the court. Wheeler v. Barker, 92 Cal. App. 2d 776, 785, 208 P.2d 68, $73-74$ (2d Dist. 1949); Preston v. Hubbell, 87 Cal. App. 2d 53, 57-58, 196 P.2d 113, 115-16 (2d Dist. 1948). Furthernore, it seems illogical to assume that a dangerous patient, whatever that means, is necessarily one incapable of appreciating the nature, extent and consequences of the risks involved, as incompetency is implicitly defined by the court. E.g., Bonner v. Moran, 126 F.2d 121, 122 (D.C. Cir. 1941), cited in Cobbs v. Grant, 8 Cal. 3d 229, 244, 502 P.2d 1, 10, 104 Cal. Rptr. 505, 514 (1972).

Second, and much more important for present purposes, it is the risks inherent in beginning therapy, such as the often hidden risk that the therapist might need to breach confidentiality under certain circumstances, not the risks accruing at the time the therapist has decided to take some action (the generally understood risks of commitment), which need disclosure by the therapist to afford informed consent to the patient contemplating treatment. Consent in the latter context-when refusal by the patient means breach of confidentiality nonetheless-has little meaning, although the therapist might still be expected to ask. Sce, e.g., CaL. EvID. CoDE $\$ 1024$, Legislative Comment (West 1966) (no privilege wheu need based on dangerousness, and patient has refused to consent to disclosure). Only when the patient has been given a meaningful choice whether to begin a treatment process which at some point might necessitate a personal injury with no opportunity then to decline this effect would the Cobbs requirement of informed consent seem fulfilled. See notes 166-70 and accompanying text infra.

165. See note 158 supra.

166. Prosser, supra note 12, at 327-35; Fleming, supra note 12, at 150.

167. 8 Cal. 3d 229, 242, 502 P.2d 1,-9, 104 Cal. Rptr. 505, 513 (1972).

168. The court in In re Lifschutz made both of these points quite well: "[W]e are necessarily mindful of the justifiable expectations of confidentiality that most individuals seeking psychotherapeutic treatment harbor," expectations that indeed may be based on ignorance of the existing legal environment, 2 Cal. 3d 415, 431, 467 P.2d 
mission to treatment, with its typical demands upon the patient to reveal intimacies, thus involves risks of a kind often unknown to the patient unless he is made aware of them at the commencement of therapy. ${ }^{169}$ Finally, as was observed earlier, the degree of dependence and trust that the patient places in the psychotherapist certainly equals and likely exceeds that of the usual physician-patient relationship. ${ }^{170}$ It is this trust which strongly mandates that the psychotherapist take the initiative in cautioning the patient lest he be lulled into a false sense of security.

Certainly the Cobbs analogy must be tempered by observing that there the informed consent requirement was weighed against injury to the patient, whereas here it must be balanced against preventing injury to third persons. But while prevention of injury is unquestionably a proper objective, courts have long acknowledged that it can be bought too dearly. ${ }^{171}$ When the means for accomplishing the objective are unacceptable, they tend to weaken the legitimacy of that very objective. ${ }^{172}$ For example, where the psychotherapist's desire to protect third persons entails a conscious design to mislead patients by encouraging them to make potentially damaging disclosures, ${ }^{173}$ it conflicts with the therapist's fiduciary obhigation. The therapist's primary duty is to the patient; ${ }^{174}$ intentional misrepresentation, therefore, is ethically untenable and should be repudiated.

Moreover, in the psychotherapeutic context the means for protecting third persons may involve infringements of privacy; they may

557, 567, 85 Cal. Rptr. 829, 839 (1970), but unlike patients, "psychotherapists certainly have been aware of the limitations of their recognized privilege for some time." Id. at 426, 467 P.2d at 564, 85 Cal. Rptr. at 836. See also Psychiatric News, Apr. 19, 1972, at 27, col. 1 .

169. See Underprivileged Communications, supra note 62, at 1069.

170. See notes 30-31 and accompanying text supra.

171. Several rules of criminal procedure, inclnding the exclusionary rule and its progeny and the entrapment defense, have developed precisely from the notion that prevention of crime can be bought at unreasonable prices. E.g., Miranda v. Arizona, 384 U.S. 436 (1966); Mapp v. Ohio, 367 U.S. 643 (1961); Sherman v. United States, 356 U.S. 369 (1958). As one jnist has noted:

By measures such as these [use of police dogs, or even resort to a "full-scale reign of terror"], perhaps even the most unsocialized and antisocial people can be forced into a kind of submission-and we wouldn't have to bother to look at the reasons for their plight. But at what a price!

Bazelon, supra note 109, at 25 (emphasis in original). See also Friendly, The Bill of Rights as a Code of Criminal Procedure, 53 CaLIf. L. Rev. 929 (1965).

172. This point is persnasively made by Professor Herbert Packer. H. PACKER, The Limits of the CRIminal Sanction 58-61 (1968).

173. For a discussion suggesting that the contradictions inherent between the psychotherapist-patient privilege, CAL. Evid. CODE \& 1014 (West Supp. 1974), and the dangerous patient exception, CAL. EviD. CODE $\S 1024$ (West 1966), might well indicate a subtle policy of entrapment, see note 56 supra.

174. See generally, DAWmoff, supra note 27 , at $43-53$. 
even involve commitment, a deprivation of liberty similar to incarceration. For this reason Miranda v. Arizona ${ }^{175}$ by analogy reinforces a requirement of informed consent in psychotherapy. Whether the Miranda rules governing informed waiver in police questioning are based on the coerciveness inherent in custodial interrogation ${ }^{176}$ or the basic unfairness of using statements made without an awareness of possible consequences, ${ }^{177}$ their rationale seems equally applicable to psychiatric disclosures. Although the purposes and underlying relationship involved in police questioning may differ significantly from those of psychotherapeutic sessions, the coercive element in each is similar in degree if not in kind. Indeed, for the patient who is unaware of the possible implications of revealing certain matters to his therapist, psychotherapy might well be inore coercive than police interrogation. In addition to the patient's general assumption of confidentiality and his dependence upon his therapist, ${ }^{178}$ it will usually be stressed in psychotherapy that the patient's improvement rests on the fullest personal disclosure. ${ }^{179}$ In such an atmosphere, where security is seemingly available and disclosure appears personally beneficial, powerful elements of inducement are present which do not exist in custodial questioning by police. Taking a leaf from Miranda, then, it may be argued that due process imterests will be advanced if psychiatric disclosures made without informed consent are at least excluded from commitment proceedings. ${ }^{180}$ Furthermore, a patient should be able to gain his release upon a showing that such disclosures were used in his commitment. ${ }^{181}$

175. 384 U.S. 436 (1966).

176. Id. at $456-58$.

177. See id. at 469.

178. See notes $162-63,168-70$ and accompanying text supra.

179. E.g., HALleCK, supra note 46, at 119.

180. Preliminarily the question arises whether emergency detention is in effect a commitment "proceeding." In California such detention requires an application in writing and an admissions determination by the facility. CAL. WELF. \& INST'NS CODE $\$ 5150$ (West Supp. 1974), \$ 5151 (West 1972). Thns, it would appear more accurate that emergency detention be classified as a "proceeding" rather than viewed, say, as merely analogous to arrest. Beyond this are explicit statutes negating privilege in commitınent proceedings. E.g., CAL. EvID. CODE $\$ \S 982,1004$ (West 1966) (husband-wife and physician-patient privileges respectively); section 1024, the dangerous patient exception, is to be interpreted as parallel to these. CAL. Evid. CoDE $\$ 1024$, Legislative Comment (West 1966); see note 196 and accompanying text infra. The important question, however, is whether an informed consent requirement should be read into or with these statutory exceptions, enforceable by civil hability, Cobbs v. Grant, 8 Cal. 3d 229, 502 P.2d 1, 104 Cal. Rptr. 505 (1972), or by exclusion of the evidence. See, e.g., Miranda v. Arizona, 384 U.S. 436 (1966).

181. Miranda violations are considered prejudicial per se; it is a truly prophylactic rule. 384 U.S. at 476-77. It shonld be noted, however, that the Miranda decision has been given only limited retroactivity. Johnson v. New Jersey, 384 U.S. 719 (1966). See also Linkletter v. Walker, 381 U.S. 618 (1965). 
The argument that a requirement of informed consent would defeat the trust relationship, without which successful therapy cannot prosper, ${ }^{182}$ may be countered by observing that the possible jeopardy to effective therapy is far from clear. As discussed earlier, ${ }^{183}$ there is hittle evidence that the present qualified confidentiality deters patients or interferes with treatment. Besides, a prominent school of modern therapy considers disclosure by patients of future intentions unnecessary, even detrimental, to successful treatment. According to this view feelings are the vital concern; facts have only historical and background inportance, and the disclosure of intentions, factual in nature and future in time, is both dilatory and irrelevant to the ultimate aim of putting the patient in touch witl present, underlying feelings. ${ }^{184}$ Finally, in climical practice pretherapy agreements between therapist and patient to limit the area of discussion are not at all unusual. ${ }^{185}$ In short, effective treatment is quite possible with restricted therapy discussion which specifically excludes disclosing future intentions.

To suminarize, vital interests of all psychiatric patients are threatened by pressures upon psychotherapists to take protective action when imvolved with potentially dangerous patients. Often patients are unaware of these threats and assume a security which is in reality unavailable. An overriding concern, therefore, is the protection of these unwary patients from self-threatening disclosures. A requirement of full disclosure and informed consent along the lines of Cobbs $v$. Grant, ${ }^{186}$ and in light of Miranda $v$. Arizona, ${ }^{187}$ inight well serve, as a-start at least, to protect these vital interests.

\section{III}

\section{How to Resolve the Psychotherapist's Dilemma}

It is easier to identify the conflicting interests of the patient and his potential victim than to resolve the therapist's dilemma of how to acquit himself of his responsibility to both. Before venturing soine specific thouglits of our own toward a resolution, it may be useful to look at the legislative scene on the chance that it might afford a sense of direction, if not a clear-cut answer.

182. One might ask, however, whether trust can exist at all when one party in a knowledgeable position about the nature of the risk-taking, the therapist, refuses to share his knowledge with the uninformed party facing the risks, the patient.

183. See notes 54-80 and accompanying text supra.

184. This school is generally associated with the humanistic psychology movement. See generally F. Perls, Gestalt Therapy Verbattm (1969); C. Rogers, On Becoming a Person (1961).

185. See note 70 supra.

186. 8 Cal. 3d 229, 502 P.2d 1, 104 Cal. Rptr. 505 (1972).

187. 384 U.S. 436 (1966). 


\section{A. Legislation}

As has been noted throughout, legislative bodies in California and in other states have addressed themselves to several aspects of the treatment of mental patients, including matters affecting the relationship between therapist and patient. ${ }^{188}$ But legislative intervention often has been interstitial and fragmentary. Not only do the statutory terms call for careful analysis and caution against overbroad construction, but an equally disciplined approach is required to distill a broader implicit legislative policy as a clue or guide on analogical issues.

In this respect, the new psychotherapist-patient privilege provisions of the Evidence Code play a central role, ${ }^{189}$ reflecting as they do a sensitive understanding of the delicate nature of that relationship. ${ }^{190}$ Section 1014 enacts the "privilege to refuse to disclose and to prevent another from disclosing a confidential commumication between patient and psychotherapist."191 This patient's privilege clearly

188. Relevant excerpts from selected California provisions are provided throughout the article. E.g., CAL. EVID. CODE $\$ 1014$ (West Supp. 1974) (psychotherapist-patient privilege), at note 191 supra; $\S 1016$ (West 1966) (patient-litigant exception), at note 59 supra; $\$ 1024$ (West 1966) (daugerous patient exception), at note 194 supra; CAL. Welf. \& lNST'NS CODE $\$ 5150$ (West Supp. 1974) (emergency commitment), at note 138 supra.

189. CaL. Evid. Code $\S \S 1010-26$ (West 1966) and (West Supp. 1974). The psychotherapist-patient privilege, euacted as part of the Evidence Code in 1965, evolved from the psychologist-client and physician-patient privileges. Ch. $2320, \S 1$ [1957] Cal. Stats. 4038 (repealed 1965) (former Cal. Bus. \& Prof. Code $\$ 2904$ (West 1962)); former CaL. Code CTv. Pro. $\$ 1881$ (West 1957) (enacted 1872, repealed 1965). The Legislative Committee comment enumerates three differences between the psycliotherapist-patient and physician-patient privileges. CAL. EvID. CODE \$ 1014, Legislative Comment (West 1966).

190. Cal. Evid. CoDe $\$ 1014$, Legislative Comment (West 1966). See note 54 supra.

191. Section 1014 of the Evidence Code reads:

Subject to Section 912 and except as otherwise provided in this article, the patient, whether or not a party, has a privilege to refuse to disclose, and to prevent another from disclosing, a confidential communication between patient and psychotherapist if the privilege is claimed by:

(a) The holder of the privilege;

(b) A person who is authorized to claim the privilege by the holder of the privilege; or

(c) The person who was the psycliotherapist at the time of the confidential counmunication, but such person may not claim the privilege if there is no lolder of the privilege in existence or if he is otherwise instructed by a person authorized to permit disclosure.

The relationship of a psychotherapist and patient shall exist between a psychological corporation as defined in Article 9 (commencing with Section 2995) of Chapter 6.6 of Division 2 of the Business and Professions Code or a licensed clinical social workers corporation as defined in Article 5 (commencing with Section 9070) of Chapter 17 of Division 3 of the Business and Professions Code, and the patient to whom it renders professional services, as well as between such patients and psychotherapists employed by such corporations to render services to such patients. The word "persons" as used in 
has its correlative in the therapist's duty of non-disclosure-a duty which, we may readily concede, is not necessarily limited to the evidentiary context to which, strictly speaking, the relevant sections of the Evidence Code are confimed. There is a strong case for saying that these sections reflect a legal duty of confidentiality resting on the "psychological, social, historical and moral importance to human freedom"192 which transcends the merely exclusionary function of evidentiary privileges. Such a duty could be enforced by the patient against the therapist to prevent unauthorized disclosures outside the forensic context-arguably imcluding disclosures to the police or a person threatened by the patient. ${ }^{103}$ The implication is that the therapist's duty of confidentiality to the patient is imcompatible with a right, let alone an obligation, on his part to violate this confidence to ensure the safety and security of others.

This argument would, however, overlook the import of section $1024,{ }^{104}$ the "dangerous patient" exception which, as mentioned earlier, negates the privilege if the therapist believes the patient to be dangerous to himself or to others. ${ }^{105}$ This demal of privilege is not in terms limited to evidence in commitment proceedings. ${ }^{196}$ Indeed, the very breadth of the mandate suggests an overriding legislative policy of subordinating the patient's interest in confidentiality to a more exigent concern with public safety.

Compulsion to testify, of course, is by no means the same as a duty to imitiate disclosure to the police or others outside a forensic

this subdivision includes partnerships, corporations, associations and other groups and entities.

CAL. Evid. Code $\$ 1014$ (West Supp. 1974) (emphasis in original).

192. Louisell, Confidentiality, Conformity and Confusion: Privileges in Federal Court Today, 31 TuL. L. Rev. 101, 114-15 (1956).

193. Tarasoff v. Regents of Univ. of Cal., 108 Cal. Rptr. 878, 888-89 (1st Dist. 1973) (Elkington, J., concurring), hearing granted, Cal. Sup. Ct. (Sept. 6, 1973).

194. The statutory exception to the psychotherapist-patient privilege reads:

There is no privilege under this article if the psychotherapist has reasonable cause to believe that the patient is in such mental or emotional condition as to be dangerous to himself or to the person or property of another and that disclosure of the communication is necessary to prevent the threatened danger.

CAL. Evid. Code $\& 1024$ (West 1966).

195. For a fuller discussion see note 56 supra.

196. Compare CAL. Evm. CoDE $\S \S 982,1004$ (West 1966) (denying the marital and physician-patient privileges 'in a proceeding to commit ['either spouse,' or 'the patient'] . . because of his alleged mental condition") with $\S 1024$ (West 1966), which makes no unention of committal proceedings although comments to the section clearly regard it as parallel to sections 982 and 1004. "This section provides a narrower exception to the psychotherapist-patient privilege than the comparable exceptions provided by Section 982 . . . and Section 1004." CAL. EvID. CODE $\S 1024$, Law Revision Commission Comment (West 1966) (emphasis added). Quaere, how can section 1024 constitute a narrower exception than sections 982 and 1004 unless the phrase "in a proceeding to counmit the patient" is implied? 
context. Nor is there any logical nexus between them. A legislator or other decision maker could well decide to take one step, but not the other. Yet while there is no basis for any compelling inference, we are not precluded from taking soundings of a possible legislative intent. Since in legal proceedings when the safety of the patient or of third parties is at stake, confidentiality must evidently yield to an interest in ascertaiming the truth, one would think that the same balance would be struck when the therapist is confronted, not in the courtroom but on the firing line, so to speak, with an emergency decision of what steps to take in order to avert an imminent peril. If the need for the therapist's evidence is deemed so high as to deny him a privilege in the courtroom, there is all the more reason to release him from his bond of confidentiality when he must act, if at all, instantly.

While the preceding argument supports the therapist's less controversial right to make a disclosure, it admittedly does not impose on him a duty to do so. But the argument does not have to be pressed that far. For if it is once conceded, as was argued in the first part of this article, that a duty in favor of the patient's foreseeable victims would accord with general principles of tort liability, we need no longer look to the statute for a source of duty. It is sufficient if the statute can be relied upon, proprio vigore or at least by inference, for the purpose of countering the claim that the needs of confidentiality are paramount and must therefore defeat any such hypothetical duty. In this more modest perspective, the Evidence Code's "dangerous patient" exception may be invoked with some confidence as a clear expression of legislative policy concerning the balance between the confidentiality values of the patient and the safety values of his foreseeable victims.

Moreover, several statutory provisions outside the Evidence Code specifically confer powers and duties on psychotherapists. Thus section 5150 of the Welfare and Institutions " Code $^{197}$ provides that when a person is "a danger to others, or to himself," a hospital's psychiatric staff and certain other designated officials may upon reasonable cause take that person into custody for 72-hour treatment and evaluation. ${ }^{108}$ This provision confers only a power, not a duty, but compul-

197. CAI. WelF. \& INST'NS CODE $\S 5150$ (West Supp. 1974), quoted at note 138 supra.

198. Such officials are also clothed with immunity. CAL. WELF. \& INST'NS CODE \$. 5154 (West 1972). On the other hand, persons petitioning for a commitment ("court-ordered evaluation") are given no immunity, whereas prior to the thoroughgoing reform of 1967 (known as the Lanterman-Petris-Short Act) at least an "attending physician" had such an immunity under former section 5551. Ch. 391, §5, [1965] Cal. Stats. 1654. See note 45 supra. The statute's concern for privacy and confidentiality incident to such commitment is embodied in CAL. WELE. \& INST'NS 
sion backed with criminal sanctions is behind the requirement that physicians file a repont on any patient treated for knife or gun wounds or other violation of penal law, ${ }^{109}$ as well as on any minor patient whose mjuries appear other than accidental. ${ }^{200}$

Lastly, the California Government Code confers a plethora of specific immunities on public employees and entities charged with making decisions on the commitnent or discharge of mental patients. ${ }^{201}$ These immunities seen1 to reflect a desire to shield public officials charged with the unenviable responsibility of these delicate decisions from the harassnient of litigation and liability rather than any transcending conclusion that psychotherapy, and especially the therapist's position between patient and society, should on primciple lie beyond the province of legal process. At most, these immunities are designed not to impede or discourage professional decisions which promote public safety.

This canvass of relevant statutes raises several points: First, the general principle emerging from the privilege statutes is simply that confidentiality deserves substantial but not absolute protection, and that it must yield at times to certain values of societal safety. Second, the legislature has specified a few instances in which confidentiality must yield under threat even of criminal sanctions. And third, in other contexts the legislature, through grants of immunity, has struck a balance favoring confidentiality and freedom of professional action over safety: These random instances of statutory imtervention hardly reveal any overriding legislative policy to tip the scales toward either value-confidentiality or safety. Nor in the absence of any expressed intention to lay down a comprehensive code for psychotherapy, can they be interpreted as representing an exclusive statement of the duties owed by psychotherapists in the interests of public safety under either criminal or tort law. We are therefore thrown back on our own resources.

\section{B. Toward a Compromise Formula}

In the quest for a formula which would deal fairly with the concerns of both patients and victims, we have identified a number of specific factors which might help in establishing heuristic ground rules. These factors can be grouped into four sets.

First are factors leading to accuracy in assessing dangerousness, for maximizing such accuracy obviously serves the best interests of

CODE $\$ \S 5200,5203$, and 5328 (West 1972), but none of this can be interpreted as evidence of an intention to discourage the initiative of psychotherapists in appropriate circumstances.

199. Cal. Pen. Code $\$ \S 11160-62$ (West 1970) and (West Supp. 1974).

200. Cal. Pen. Code $\$ 11161.5$ (West Supp. 1974).

201. See-CAL. Gov'T CODE $\$ \$ 854.8,855.8,856,856.2,856.4$ (West 1966). 
all parties. Psychotherapy is a relatively new science with some promise of progressive improvement in diagnostic and therapeutic skills. Although there may be little prospect of giving more precision to the criterion "dangerous to self or others,"202 a useful control in counteracting psychotherapists' propensity to overpredict dangerousness would be to require that they seek a second independent professional opinion before taking imitiatives in breach of confidentiality to protect third parties.

Next in line is the timing of disclosure. To the threatened victim it matters little how close the peril comes so long as it is ultimately avoided. Overcaution, however, may harm the patient in the long as well as the short run, since he faces severe and perhaps avoidable detriment if measures are taken against him prematurely. It must be recalled that therapy often involves periods of heightened instability. ${ }^{203}$ This difficult time nay result in damage, but more often it brings about improvenent or cure. From this it follows imperatively that no imitiative be taken until danger is truly imminent. ${ }^{204}$ The standard of imminent danger has an honored place in our jurisprudence as the point at which first amendment rights may be sacrificed to peremptory demands of public safety. ${ }^{205}$ In the psychotherapy context it may serve as the point beyond which the patient's interests may be justifiably subordinated to concern for the security of his would-be victims. No doubt the credibility of the threat and the severity of the harm threatened are as iniportant ingredients in imminence of the danger as its nearness in time. ${ }^{206}$

Third, when danger is imminent and action of some sort imperative, the therapist should select the form of intervention with the least harmful impact upon the patient's interests. In some cases the patient's vengeful intent is firmly set, in others it is not. In some the potential victim is specific and identified, in others the victim is un-

202. One commentator is more optimistic, suggesting that the test for commitment be "only when the finder of fact is persuaded 'by clear and convincing evidence" that the person in question is "highly likely to commit a dangerous act," "with "the predicted harm be[ing] personal injury and not merely property damage or some offense against public decency." Civil Commitment, supra note 49 , at 1291 . The Wexler study suggests that such judgments might be required to be based only upon actual daugerous behavior in the recent past in order to meet constitutional objections. Wexler, Scoville, et al., supra note 49, at 99-100.

203. See note 40 supra.

204. Interview with Bernard Diamond, Psychiatrist, Professor of Law and Criminology, University of California, in Berkeley, Cal., Oct. 22, 1973.

205. See, e.g., Brandenburg v. Ohio, 395 U.S. 444 (1969); Yates v. United States, 354 U.S. 298 (1957).

206. In first amendment cases the courts "must ask whether the gravity of the 'evil,' discounted by its inprobability, justifies such invasion of free speech as is necessary to avoid the danger." Dennis v. United States, 341 U.S. 494, 510 (1951). 
known or the threat generalized. Sometimes it may be possible to protect the prospective victim without the patient ever knowing, at other times only physical restraint will suffice. The range of alternatives open to the therapist is wide: he may choose to warn the victim or the police, with or without disclosure to the patient in advance or afterwards; he may persuade the patient to accept voluntary commitment, refer him to a halfway facility of some kind, or recommend involuntary commitment. Whatever the choice, it must be weighed against overcaution. Like premature action, action more drastic than necessary to afford reasonable protection for the third party subjects the patient to unwarranted invasion of his rights.

Finally, there is the role of informed consent. Informmg the patient before therapy of the limits to confidentiality and the implicit risk to him of disclosures beyond the agreed limits has two-fold importance. First, it is an essential condition for the patient's right to accept or reject therapy under conditions of informed consent. ${ }^{207}$ Second, it may lielp make assessment of dangerousness more accurate by screening out some exaggerated threats of harm. The therapist nay properly give more weight to a patient's confessions when made with awareness that they might be disclosed to others. Admittedly, such a policy of advance warning will probably discourage some disclosures by patients, ${ }^{208}$ but this is not too high a price for maintaining the integrity of the therapist-patient relationship. In any event, inforined consent is proposed as a highly desirable but not absolutely necessary condition for any subsequent disclosure by the therapist. Thus there may be times when a patient springs a serious homicidal plan on the therapist entirely unexpectedly and it is too late to utter the cautionary warning. As previously pointed out, although $M i$ rand $a^{209}$ is helpful, it is not exactly on all fours. ${ }^{210}$ For one thing, it is not the purpose of therapy, as it is of police interrogation from the outset, to elicit a confession. Moreover, society's mterest in preventing threatened violence is infinitely greater than its interest in making it easier to prove the commission of a crime already committed.

Implicit in the preceding comments is the conviction that the appropriate standard for disclosure is a lay standard rather than a professional one. Furtherinore, the standard and compliance with it should be determined by judge and jury, not by the professional

207. See notes 159-87 and accompanying text supra.

208. The California legislature in enacting the "dangerous patient" exception was aware of the possible interference posed by any inroads upon confidentiality, but found the balance properly struck. CAL. EvID. CODE $\$ 1024$, Legislative Comment (West 1966) (although exception might inhibit the relationship between the patient and his psychotherapist to a limited extent, it is essential).

209. Miranda v. Arizona, 384 U.S. 436 (1966).

210. See notes 175-81 and accompanying text supra. 
practice of psychotherapists as evidenced by expert opinion. ${ }^{211}$ The reason for the familiar contrary rule in adjudging physicians is not that medical problems call for peculiarly delicate balancing between countervailing risks, or that physicians deserve a great deal of discretion beyond the range of judicial scrutiny. Rather, the lay person is not credited with sufficient knowledge to pass an informed judgment about clinical matters. ${ }^{212}$ Thus, according to the better opinion now prevailing in California, the patient's right to informed consent is no longer prejudged by the professional custom in the community, but by the legal standard of due care set by judge and jury. ${ }^{213}$ As Justice Mosk, speaking for the California Supreme Court, succinctly put it:

A medical doctor, being the expert, appreciates the risks inherent in the procedure he is prescribing, the risks of a decision not to undergo the treatment, and the probability of a successful outcome of the treatment. But once this information has been disclosed, that aspect of the doctor's expert function has been performed. The weighing of these risks against the individual subjective fears and hopes of the patient is not an expert skill. ${ }^{214}$

In psycliotherapy, too, expert testimony on such questions as diagnosis relating to the imminence of danger obviously demands respect, but the ultimate question of resolving the tension between the conflicting interests of patient and potential victim is one of social policy, not professional expertise. We may sympathize with the therapist confronted with a decision at once delicate and awesome, but this is hardly umque nor sufficient for a claim to immunity. In sum, the therapist owes a legal duty not only to his patient, but also to his patient's wouldbe victim, and is subject im both respects to scrutiny by judge and jury.

\section{CoNCLUSION}

It is the easier and more attractive alternative for courts to skirt the difficult social policy judgments inherent in the therapist's decision whether or not ito act when confronted witl a possibly dangerous patient and an identifiable potential victim. The onerous task of placing proper weights in proper scales and assessing the balance encourages judge and jury to defer to the professional judgment of the

211. See Ennis \& Litwack, supra note 86 , at 734-43.

212. "[W] lay juror, medical expert opinion is necessary . . . " Cobbs v. Grant, 8 Cal. 3d 229, 236, 502 P.2d 1, 5, 104 Cal. Rptr. 505, 509 (1972).

213. Cobbs v. Grant, 8 Cal. 3d 229, 502 P.2d 1, 104 Cal. Rptr. 505 (1972); Canterbury v. Spence 464 F.2d 772 (D.C. Cir. 1972). Most other jurisdictions, alas, still lag behind. See Note, Informed Consent in Medical Malpractice, 55 CaLIF. L. REv. 1396 (1967).

214. Cobbs v. Grant, 8 Cal. 3d 229, 243, 502 P.2d 1, 10, 104 Cal. Rptr. 505, 514 (1972). 
therapist. As has been demonstrated, however, such an abdication is unwarranted. The therapist's duties flow to patient, victim, and society. The patient risks much by entering therapy; looking to the doctor for cure, he readily confides, often unaware of the grave consequences awaiting an improvident disclosure. But society also looks to the therapist; viewing him as a safety valve, relying on his skill to short-circuit dangerous potentialities, hoping his judgment will accurately assess when skills beyond his own are required to avert harm. Yet the therapist's predictive ability has been tested and found wanting. Deference to such inability should not be tolerated, for upon these predictions turn the interests, even the constitutional rights, of the patient, as well as the imterests of the victim, perhaps including life itself. Statutory law provides at best only partial answers. The most difficult questions still await case-by-case resolution by enlightened and sensitive courts. 


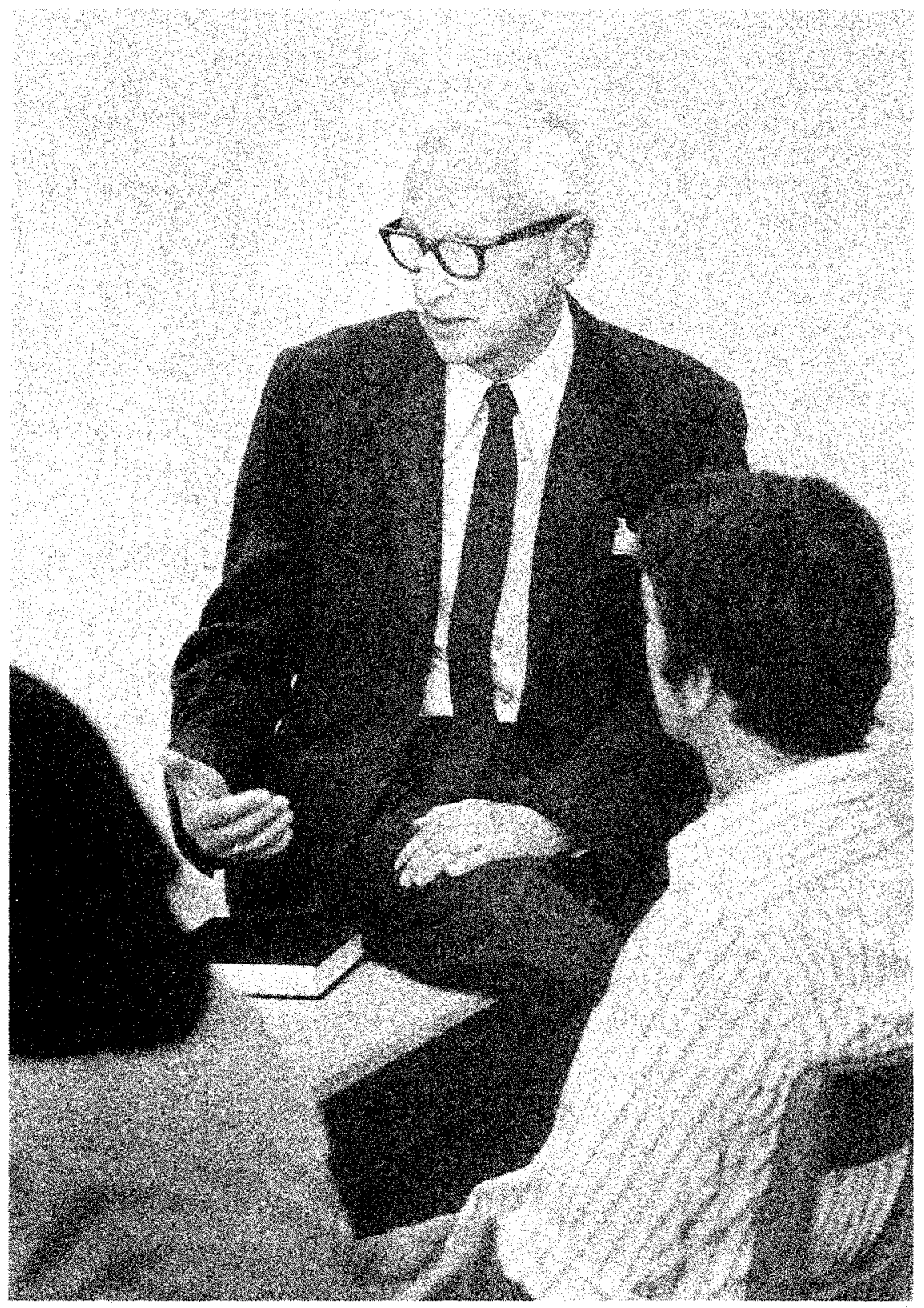

ALBERT A. EHRENZWEIG 
Herma Hizl Kay, B.A., J.D., Professor of Law

Friedrich Kessler, DR. JuR., M.A., LL.D., Professor of Law

Adrian A. Kragen, A.B., J.D., Shannon Cecil Turner Professor of Law, Emeritus

StePhan George KutTner, Diploma in Law, J.U.D., Professor of Law and Director of The Robbins Canon Law Collection

William T. LaUbe, JR., A.B., J.D., LL.M., A.F. and May T. Morrison Professor of Law, Emeritus

David W. LouiselL, B.S.L., J.D., Elizabeth Josselyn Boalt Professor of Law

Paul L. McKaskle, B.S., J.D., Visiting Professor of Law

JoHn K. McNulTy, A.B., LL.B., Professor of Law

Paul Mishkin, A.B., LL.B., Professor of Law

Robert H. MNookin, A.B., LL.B., Acting Professor of Law

VAclav Mostecky, Dr. Jur., M.A., M.S. in L.S., Professor of Law and Law Librarian

Frank C. Newman, A.B., LL.B., LL.M., J.S.D., Jackson H. Ralston Professor of International Law

John T. Noonan, JR., B.A., M.A., Ph.D., LL.B., Professor of Law

Henry Ramsey JR., A.B., LL.B., Acting Professor of Law

Stefan A. Riesenfeld, Dr. Jur., Dott. in guir., LL.B., S.J.D., B.S., Dr. Jur.h.e., Emanuel S. Heller Professor of Law

Sho SATo, A.B., LL.B., Professor of Law

HAL S. ScotT, B.A., M.A., J.D., Acting Professor of Law

Bernard Shapiro, A.B., LL.B., Visiting Professor of Law

ArThur H. Sherry, A.B., J.D., Walter Perry Johnson Professor of Law and Professor of Criminology

Michael E. SMTTH, B.A., M.A., J.D., Professor of Law

Preble Stolz, A.B., J.D., Professor of Law

LAWRENCE M. Stone, A.B., LL.B., Professor of Law

Stephen D. Sugarman, B.S. B.A., J.D., Acting Professor of Law

Lawrence A. Sullivan, B.A., LL.B., Professor of Law

Justin SweEt, B.A., LL.B., Professor of Law

JAN VeTTER, B.A., LL.B., Professor of Law

JoHN R. WILKINS, B.A., LL.B., Professor of Law, Emeritus

\section{Lecturers in Law}

Roger H. BERnhardt, A.B., J.D.

RichaRd COTTON, A.B., LL.B.

Howard N. EllmaN, A.B., LI.B.

JEROME B. FALK, JR., A.B., J.D.

STEPHEN R. FinN, B.A., J.D.

K. Bruce Friedman, A.B., LL.B.

Chris G. Gasparich, A.B., LL.B.

EDWIN A. Heafey, JR., A.B., LL.B.

MARVIN S. KAYNE, B.S., J.D.

DAVID L. KIRP, B.A., LL.B.

STANLEY B. LUBMAN, A.B., LL.B., LL.M., J.S.D.
KenNeth F. Phillips, A.B., J.D.

E. LEWIS REID, B.S.E.E.

Peter E. Sitkin, B.A., LL.B.

Douglas G. SYKES, B.S., M.B.A., J.D.

\section{Associates in Law}

Arthur R. Abelson, B.A., J.D.

Robert A. BARr, S.B., J.D.

LAurie S. DEUTSCh, B.A., J.D.

RichaRd J. FINK, B.A., J.D.

Tanya M. NeIMAN, A.B., J.D.

JoHN C. TYNDALL, A.B., J.D. 